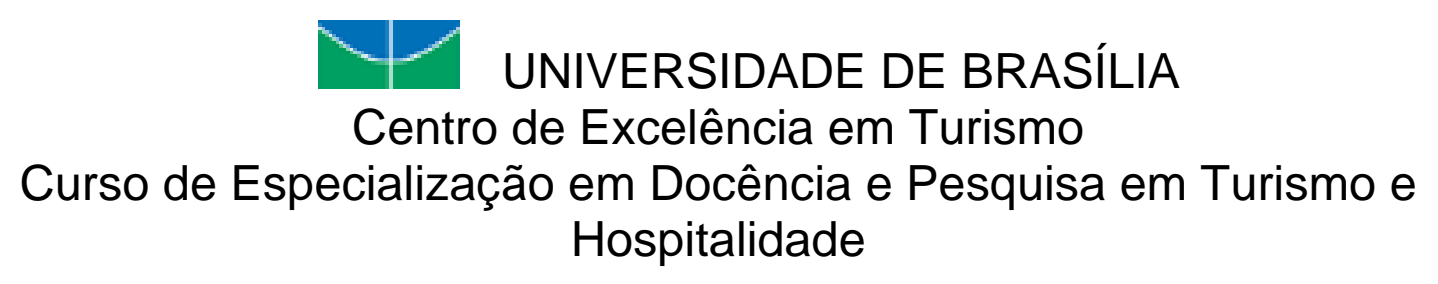

TURISMO NÁUTICO

O LAGO PARANOÁ E SUAS POTENCIALIDADES PARA O LAZER E O ENTRETENIMENTO

- UM ESTUDO DE CASO -

\title{
GISELA PELEGRINELLI
}

\section{Orientadora: IARA LÚCIA BRASILEIRO}

Monografia apresentada ao Centro de Excelência em Turismo da Universidade de Brasília como requisito parcial para a obtenção do certificado de Especialista em Docência e Pesquisa em Turismo e Hospitalidade.

Brasília-DF, Fevereiro, 2004 


\begin{abstract}
UNIVERSIDADE DE BRASÍLIA
Centro de Excelência em Turismo

Curso de Especialização em Docência e Pesquisa em Turismo e Hospitalidade
\end{abstract}

\title{
TURISMO NÁUTICO \\ O LAGO PARANOÁ E SUAS POTENCIALIDADES PARA O \\ LAZER E O ENTRETENIMENTO \\ - UM ESTUDO DE CASO -
}

\section{GISELA PELEGRINELLI}

Banca Examinadora
Prof $^{\mathrm{a}}$ Dr $^{\mathrm{a}}$ IARA LÚCIA BRASILEIRO, Orientadora

Membro da Banca 
Ficha Catalográfica

PELEGRINELLI, Gisela

Título / Gisela Pelegrinelli

$79 \mathrm{f}$.

Monografia (especialização) -Universidade de Brasília.

Centro de Excelência em Turismo. Brasília, 2004.

Área de Concentração: Turismo

Orientadora: Prof ${ }^{\mathrm{a}} \mathrm{Dr}^{\mathrm{a}}$ Iara Lúcia Brasileiro

1. Turismo 2. Lago Paranoá 3. Lazer 
GISELA PELEGRINELLI

\section{TURISMO NÁUTICO \\ O LAGO PARANOÁ E SUAS POTENCIALIDADES PARA O \\ LAZER E O ENTRETENIMENTO \\ - UM ESTUDO DE CASO -}

Comissão Avaliadora

\section{Prof $^{\mathrm{a}}$ Orientadora}

Membro da Comissão

Membro da Comissão

Membro da Comissão 
Dedico este trabalho aos meus pais, por compreenderem e apoiarem meu período de transição que fez com que eu descobrisse novos caminhos. 


\section{Agradecimentos}

A Deus, pois sem ele nada seria possível.

À Professora Doutora lara Lúcia Brasileiro, pela orientação e dedicação neste trabalho e também, por despertar-me ainda mais para a pesquisa acadêmica.

Aos meus amigos de curso, pelo companheirismo ao longo da jornada.

A todos os amigos e familiares que souberam compreender minha ausência durante todo o curso.

A Rodrigo Rollemberg, em especial, pela disponibilidade e atenção dispensada na entrevista concedida a mim.

A todos que colaboraram direta e indiretamente na elaboração e execução deste trabalho.

Às Jornalistas Ellis Regina e Elizete Cristina, almas iluminadas que cruzaram minha vida. Vou tentar espelhar-me profissionalmente nelas, exemplos de dedicação e amor à profissão.

E finalmente, abro um espaço muito especial para agradecer a minha amiga Lili, companheira de todas as horas e grande incentivadora de minha participação neste curso. Sabe, verdadeiramente, o olhar de uma viagem, seu resgate, sua memória, suas raízes. 
“Eu sei que o Havaí não é aqui;

Que o mar está longe daqui;

Mas pra quê eu quero o mar;

Se tenho o Lago (Paranoá) para amar."

Adaptação da música "Surfista do Lago Paranoá" - Natiruts 


\section{Resumo}

Brasília é reconhecida pela UNESCO como Patrimônio Cultural da Humanidade, mesmo sendo uma cidade cuja construção ainda não foi concluída.

A criação de um lago artificial na Bacia do Rio Paranoá foi idéia do botânico Glaziou, integrante da Missão Cruls. Somente em 1955 houve a conclusão dos estudos para a efetiva criação de um Lago em torno da cidade. $\mathrm{O}$ surgimento do Lago abriu possibilidades de lazer, recreação, esporte, turismo, geração de energia e composição paisagística de Brasília e passou a ser considerado como o maior patrimônio ambiental da cidade. Após 42 anos de existência, a população do Distrito Federal já ultrapassou os dois milhões de habitantes, comprometendo a sustentabilidade da Bacia do Lago Paranoá.

A velocidade e intensidade do crescimento demográfico, ameaça a qualidade de vida do brasiliense. Medidas de ordem urbanística, ambiental, tecnológica, econômica e cultural devem ser adotadas com ampla participação da sociedade no desenvolvimento sustentável da cidade e na preservação do seu lago para as gerações futuras.

Sendo assim, faz-se necessário a implementação de um plano diretor para sua orla, relacionando seu uso para o lazer, a prática de esportes e recreação, visando identificar e incrementar suas potencialidades. Esse mesmo potencial será usado para fomentar o turismo em Brasília de forma sustentável, buscando a melhoria da qualidade de vida e da qualidade ambiental na orla do Lago.

Surgiram, então, as estratégias para implantar programas que evidenciem o turismo náutico e, conseqüentemente, traga benefícios para a comunidade em forma de geração de emprego e renda. 


\section{Abstract}

Brasília has been recognized by UNESCO as Heritage of Humanity, even though its construction is not yet finished.

Building an artificial lake in Brasilia has been the idea of the botanist Glaziou. Who integrated the Cruls Mission. Only in 1955 the studies for the effective creation of a Lake around Brasilia were completed. The lake opened possibilities for leisure, recreation, sport, energy generation, and landscape composition of Brasilia and is considered as the most important environment asset of the city. After 42 years, the population of Distrito Federal has surpassed 2.000.000 inhabitants, putting at risk the maintenance of Lake Paranoa.

The speed and intensity of demographic growth, puts at risk the quality of life of population of Brasilia. Urbanistic, environmental, technological, economic and cultural measures must be adopted, with the participation of civil society in the sustainable development of the city and in the preservation of its lake for future generations.

Hence, it is necessary that a director plan for its shores be implemented, linking its use with leisure, the practice of sports and recreation, aiming the identification and growth of its potentialities. This can be used to promote tourism in Brasilia, seeking better life quality and environment quality of the shores of the lake.

There appeared strategies to implement programs putting to the fore water tourism and, consequently, benefiting the community by the generation of jobs and income. 


\section{Sumário}

Pág.

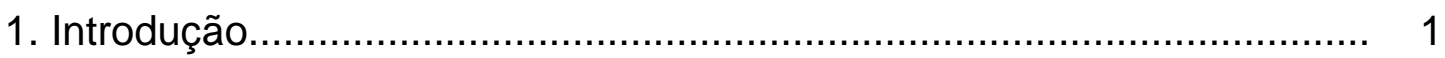

1.1. Justificativa...........................................................................

1.2. Objetivos

1.2.1. Objetivo Geral............................................................... 4

1.2.2. Objetivos Específicos.......................................................... 4

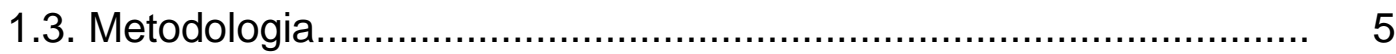

2. A Mudança da Capital: Breve Histórico................................................ 6

3. O Surgimento do Lago Paranoá

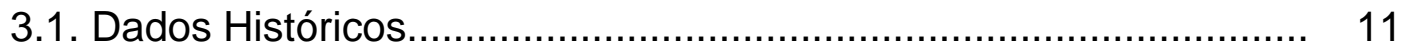

3.2. Aspectos Ambientais.............................................................. 14

3.3. Despoluição do Lago Paranoá.................................................. 15

3.4. Peixamento do Lago Paranoá.................................................... 18

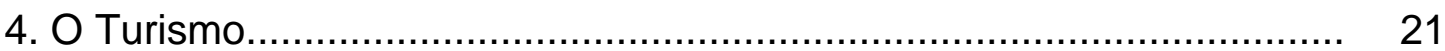

4.1. O Turismo Sustentável................................................................ 22

4.2. O Turismo em Brasília............................................................... 24

5. Projeto Orla

5.1. Pólo 1 - Pontão do Lago Norte................................................. 27

5.2. Pólo 2 - Complexo da Enseada............................................... 28

5.3. Pólo 3 - Complexo Brasília Palace.............................................. 29

5.4. Pólo 4 - Parque do Cerrado.................................................... $\quad 30$

5.5. Pólo 5 - Marina do Paranoá......................................................... 31

5.6. Pólo 6 - Centro de Lazer Beira Lago......................................... 31

5.7. Pólo 7 - Parque Tecnológico.................................................. 32

5.8. Pólo 8 - Centro Internacional................................................ 32

5.9. Pólo 9 - Parque Aquático........................................................ 33

5.10. Pólo 10 - Praça das Nações.................................................... 34

5.11. Pólo 11 - Pontão do Lago Sul................................................. 35 
6. Considerações Finais.

7. Entrevistas

7.1. Entrevista com o Ex-Secretário de Turismo do

DF - Rodrigo Rollemberg.....

7.2. Entrevista com a Secretária de Desenvolvimento

Urbano e Habitação - Ivelise Longhi. 41

8. Discussão dos Resultados. 42

9. Pontos Turísticos. 46

10. Anexos. 50

11. Referências Bibliográficas. 63 
Pág.

Mapa do Quadrilátero Cruls demarcando o Distrito Federal........................ 10

Foto da Construção da Barragem do Paranoá - 1958................................ 13

Mapa da Balneabilidade do Lago - 2003............................................. 18

Ilustrações sobre o Projeto Orla

Pontão do Lago Norte................................................................ 27

Complexo da Enseada............................................................... 28

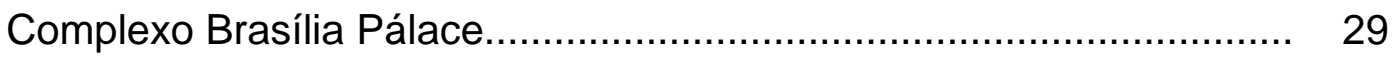

Parque do Cerrado ................................................................ 30

Centro de Lazer Beira Lago......................................................... 31

Parque Tecnológico.................................................................. 32

Centro Internacional................................................................ 32

Parque Aquático ..................................................................... 33

Praça das Nações.................................................................... 34

Pontão do Lago Sul................................................................... 35

Foto da Ermida Dom Bosco.................................................................. 46

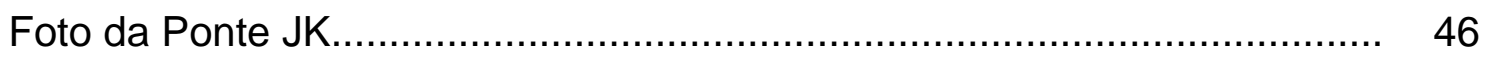

Foto da Concha Acústica...................................................................... 47

Foto do Hotel Blue Tree Park de Brasília.................................................. 47

Mapa da Localização do Hotel Blue Tree Park de Brasília.......................... 48

Foto do Lakeside Hotel.................................................................... 48

Foto da Prainha - Asa Sul............................................................ 49

Reportagem sobre o Lazer no Lago............................................... $\quad 50-52$

Reportagem sobre Pesca no Lago................................................ $\quad 53-54$

Reportagem sobre Turismo em Brasília............................................. 55-58

Reportagem sobre Peixes no Lago Paranoá............................................. 59

Reportagem sobre Esportes Náuticos no Lago Paranoá.............................. 60

Reportagem sobre Museus de Brasília............................................... 61-62 


\section{Lista de Abreviaturas}

CAESB - Companhia de Saneamento do Distrito Federal.

CONAMA - Congresso Nacional do Meio Ambiente.

DePHA - Departamento do Patrimônio Histórico e Artístico do Distrito Federal.

EMBRATUR - Empresa Brasileira de Turismo.

GDF - Governo do Distrito Federal.

IBAMA - Instituto Brasileiro do Meio Ambiente e dos Recursos Naturais Renováveis.

IPDF - Instituto de Planejamento Urbano e Territorial do Distrito Federal.

IPHAN - Instituto do Patrimônio Histórico e Artístico Nacional.

MMA - Ministério do Meio Ambiente.

NOVACAP - Companhia Urbanizadora da Nova Capital.

OMT - Organização Mundial do Turismo.

PIB - Produto Interno Bruto.

PMDB - Partido do Movimento Democrático Brasileiro.

PNPA - Programa Nacional de Pesca Amadora.

SEC - Secretaria de Estado de Cultura.

SEMARH - Secretaria do Meio Ambiente e dos Recursos Hídricos.

SETUR - Secretaria de Turismo do Distrito Federal.

TERRACAP - Companhia Imobiliária de Brasília.

UnB - Universidade de Brasília.

UNESCO - Organização das Nações Unidas para a Educação, a Ciência e a Cultura. 


\section{Introdução}

Explorar o seu potencial turístico é hoje um grande desafio para a cidade de Brasília, que reúne as condições ideais para crescer a partir do desenvolvimento desta atividade. São muitas as possibilidades que se abrem para incrementar a visitação na capital do país: Turismo de Eventos, Turismo Cívico, Turismo Arquitetônico, Turismo Rural, Turismo Místico e Religioso, Turismo Ecológico e Turismo Náutico.

Em todas essas vertentes do turismo, Brasília apresenta roteiros interessantes que atraem não apenas os visitantes de todo o país, mas também os do exterior. A capital brasileira, planejada por Oscar Niemeyer e Lúcio Costa e construída pelo então presidente da República, Juscelino Kubitschek, já conquistou o mundo por ser uma cidade moderna, de arquitetura arrojada, com grandes espaços verdes e um céu esplendoroso. Não por acaso, a cidade foi declarada pela UNESCO como Patrimônio Cultural da Humanidade.

Brasília, hoje, desperta para a potencialidade do Lago Paranoá para as atividades de lazer, onde é possível desenvolver o Turismo Náutico. Exatamente esse potencial será objeto de estudo nesse trabalho.

O Lago Paranoá, cartão postal da cidade, sempre esteve presente no processo de formação cultural da cidade. Potencialmente, é a mais importante área para o desenvolvimento turístico e atualmente está sendo usado mais pela classe média alta para o lazer, com a utilização de lanchas e iates ancorados nos inúmeros clubes e residências localizados às suas margens. $O$ Lago tem merecido pouca atenção dos órgãos públicos, com vistas a melhor utilizá-lo com outras atividades de lazer em benefício de toda a população de Brasília e, principalmente, como ponto de atração turística para os visitantes que aqui afluem. 
As tentativas para melhor explorar as potencialidades turísticas do Lago Paranoá tem sido dispersas e descontinuadas, criando frustrações e descrédito em todos os que desejam tornar o turismo de Brasília uma importante fonte de renda e emprego.

Embora em ritmo lento, o Projeto Orla, proposto pela Companhia Imobiliária de Brasília - TERRACAP - para incrementar o turismo na orla do Lago Paranoá, cuja finalização depende muito do interesse dos órgãos governamentais e iniciativa privada, está caminhando com uma nova vertente. Democratizar o uso e acesso da população ao Lago Paranoá é a diretriz que se estabelece para que Brasília, definitivamente, aproveite as condições excepcionais para a exploração turística e de lazer que o lago oferece.

Além disso, não há nada na orla que contemple o pequeno usuário. Não se sabe da existência de uma pequena rampa de acesso a quem queira colocar seu barco na água para um passeio nas águas do Paranoá. Só via clubes, pagando taxa de aluguel é possível ao brasiliense gozar desse lazer. Outro assunto estudado é a sustentabilidade do Lago e sua qualidade na água, proporcionando uma melhor qualidade de vida à população.

Com essa pesquisa pretende-se divulgar que um dos lagos mais estudados do Brasil, a "vitrine" de Brasília possibilita múltiplos usos, principalmente, sua grande vocação para o lazer e o Turismo Náutico, mas infelizmente sem qualquer estratégia ou simplesmente um plano diretor.

Este trabalho inicia-se com uma justificativa para a pesquisa, seguida de um breve histórico sobre a mudança da capital federal para o planalto central e dados sobre o surgimento do Lago Paranoá, sua importância para a cidade e que está sendo feito por sua revitalização e aproveitamento turístico.

Uma análise comparativa é feita com os depoimentos dos órgãos envolvidos, comunidade e turistas, além dos clubes que compõe a orla e outras autoridades, onde se vai percebendo as diversas implicações políticas, 
econômicas, burocráticas, sociais e ambientais que sofre um estudo com essa magnitude.

Faz-se necessário incentivar a vocação do lago para a prática de esportes náuticos, captando grandes eventos esportivos e incluindo Brasília no calendário nacional e internacional de competições náuticas. A criação de festivais aquáticos e a promoção da pesca esportiva, com a definição de áreas específicas e a introdução de novas espécies de peixes, são ações que ativariam o uso do lago pela população, constituindo-se em mais um atrativo da cidade.

Fotos e diversas matérias, correspondentes ao trabalho realizado podem ser consultadas nos anexos.

\subsection{Justificativa}

O tema que envolve o lazer no Lago Paranoá agrega vários objetivos. Desde a inauguração de Brasília, em função de sua beleza e paisagem exuberante, antevistas pelos primeiros idealizadores, o Lago Paranoá tem sido a grande atração da cidade e suas potencialidades estão relacionadas com o seu uso para a prática de esportes, lazer, recreação e o desenvolvimento de atividades voltadas para o turismo, até hoje bastante inexploradas.

Utilizar o tempo livre em atividades de lazer em Brasília não é a única expectativa do turista e nem mesmo do morador da cidade. Ambos esperam que o desenvolvimento não degrade o ambiente e que o turismo ofereça empregos e, dessa forma, melhore a qualidade de vida.

Considerando a importância da potencialidade que representa o Lago Paranoá no contexto da cidade, seria oportuno o estudo da viabilidade de 
implementação de um Plano Diretor que agregasse várias alternativas de desenvolvimento de atividades, uma vez que o Projeto Orla está "engavetado".

Também, está inclusa a análise de ações positivas e negativas, relacionadas ao impacto do turismo, que implicarão em mudanças favoráveis, as quais beneficiarão a comunidade como um todo e o próprio Lago Paranoá.

\subsection{Objetivos}

\subsubsection{Objetivo Geral}

Conhecer a potencialidade do Lago Paranoá e propor algumas ações para o incremento das atividades de lazer, ressaltando o Turismo Náutico.

\subsubsection{Objetivos Específicos}

$>$ estudar a popularização do Lago Paranoá como espaço de lazer;

$>$ verificar qual o incentivo dos clubes da orla nos eventos náuticos atualmente;

$>$ promover a melhoria da qualidade de vida da população;

$>$ contribuir para o desenvolvimento do turismo náutico na região;

> identificar os impactos que as atividades irão causar no seguimento turístico;

> gerar emprego e renda para a população local;

> averiguar se está em prática algum Plano Diretor para a orla do Lago Paranoá, garantindo sua sustentabilidade e dinamizando as atividades esportivas, de lazer e turismo. 


\subsection{Metodologia}

Para a realização deste trabalho foram utilizados vários instrumentos de pesquisa. Além de entrevistas com especialistas nos temas sob análise, nos dias 27 de outubro, 10, 18 e 21 de novembro do corrente ano.

Paralelamente à realização desta etapa, foram realizadas pesquisas no próprio Lago Paranoá, em Bibliotecas, Museus, jornais e diversos "sites" na Internet. Citamos, a seguir, detalhadamente, as pesquisas realizadas:

Leitura de livros e artigos que discorrem sobre a origem da cidade de Brasília, o Distrito Federal, Projeto Orla, meio ambiente da região, esportes, lazer e turismo sustentável.

> Visita para pesquisa ao Museu Vivo da Memória Candanga, ao Arquivo Público do Distrito Federal, às Secretarias de Estado da Administração, Obras e Turismo, à Empresa Brasileira de Turismo - EMBRATUR, ao Departamento de Arquitetura e Urbanismo da Universidade de Brasília UnB, ao IPHAN, ao Ministério do Meio Ambiente - MMA, à SEMARH, a Clubes e restaurantes da orla do Lago.

> Consulta a mapas do Distrito Federal - político, físico, multi-temporal e turístico e ao Mapa da Balneabilidade do Lago Paranoá - CAESB.

> Consulta às Bibliotecas da UnB e das Secretarias de Estado na busca de material subsidiário à pesquisa sobre o tema.

> Pesquisas em "sites" de busca, na Internet.

$>$ Leitura de artigos publicados em jornais, revistas e informativos.

> Registro fotográfico dos principais pontos turísticos do Lago Paranoá, para percepção e ilustração da pesquisa. 


\section{A Mudança da Capital - Breve Histórico}

A mudança da capital do Brasil para o interior do país, região já conhecida pelos primeiros desbravadores desde 1596, sempre permeou o imaginário de muitos políticos.

Questões político-estratégicas de segurança eram alguns dos argumentos utilizados para alimentar a defesa da transferência da capital, do Rio de Janeiro para o interior do país. O centro político sendo localizado no interior ficaria menos vulnerável a ataques de conquistadores.

Várias foram as cidades cogitadas, dentre as províncias da região para abrigar a capital. Em 1808, foi referenciado um ponto sobre o Planalto Central, cerca de 15 graus de latitude austral, que se mostrava mais vantajoso por ser próximo a cabeceira de grandes rios, a zona dos mananciais dos rios Araguaia, Tocantins, São Francisco e Paraná.

A área possuía vastas campinas para a criação de gado, pedras e madeiras de construção em abundância e toda qualidade de metais que aumentavam as potencialidades da região abrigar a capital e alimentavam os argumentos para a transferência. No Brasil Império, José Bonifácio de Andrada e Silva propôs dois nomes para a nova capital: Metrópole ou Brasília.

Em 1883, uma curiosidade: Dom Bosco, padre italiano tornado santo, em um dos seus sonhos proféticos previu uma nova civilização - "Entre os paralelos 15 e 20, no lugar onde se formará um lago, nascerá uma grande civilização e isso acontecerá na $3^{a}$ geração. Aqui será a terra prometida".

Proclamada a República em 1889 a preocupação com a mudança da capital foi materializada na constituição de 1891 que estabeleceu em seu Art.3 - "Fica 
pertencendo à União, no Planalto Central da República, uma zona de 14.400 quilômetros quadrados, que será oportunamente demarcada para nela estabelecer-se a futura Capital Federal".

Em 1892, para cumprir a Constituição, Floriano Peixoto constitui a Comissão Exploradora do Planalto Central do Brasil, que teria a finalidade de demarcar a área onde se instalaria do futuro Distrito Federal. Esta foi a primeira iniciativa do governo brasileiro, oficialmente, para concretizar a transferência da Capital para o interior. Essa Comissão realizou seus trabalhos de 1892 a 1894. Era formada por 21 pesquisadores e chefiada pelo diretor do Observatório Astronômico do Rio de Janeiro, Luiz Cruls, um notável astrônomo belga que organizou a equipe com geólogos, geógrafos, botânicos, naturalistas, engenheiros, médicos e higienistas. Seguiram a Ferrovia Mogeana, do Rio de Janeiro a Uberaba, e depois rumaram em direção ao Planalto Central, percorrendo um total de quatro mil quilômetros.

A Comissão, que ficou conhecida como "Missão Cruls", realizou vários estudos científicos, mapeando aspectos climáticos e topográficos, além de estudar a fauna, a flora e os cursos d'água do trajeto, o modo de vida dos habitantes, os aspectos urbanos e arquitetônicos das cidades pelo caminho e as doenças mais comuns nas regiões. Como resultado obteve-se o desenho do primeiro mapa do Brasil onde constava o Planalto Central A "Missão Cruls" identificou a zona pré-definida na Constituição, demarcando o "quadrilátero Cruls", criando oficialmente a expressão "Distrito Federal". Em 1894, Cruls recebeu a incumbência de presidir a Comissão de Estudos da Nova Capital da União. Era ao início da segunda missão Cruls (Relatório Cruls, p.108-110).

A segunda missão Cruls tinha a missão de escolher o local definitivo da nova capital. A ela se juntou o naturalista e botânico A Glaziou. Foi esse botânico que fez as primeiras referências sobre a possibilidade de formação de um lago em torno da futura capital. Ele observou a planície e chamou a atenção para a possibilidade da existência de um lago em "tempos de outrora" e a possibilidade de criação de um novo a partir da construção de uma barragem, aproveitando as qualidades da área. 
Os trabalhos da nova Missão Cruls se estenderam até 1896, quando as idéias sobre a transferência da capital foram paralisadas, temporariamente, após a saída de Floriano Peixoto do Governo. Somente em 1922, no dia 7 de setembro, foi lançada a Pedra Fundamental para a construção da nova capital, no Morro do Centenário, Serra da Independência, a 9 quilômetros de Planaltina, na época, cidade do estado de Goiás.

Novos estudos sobre o assunto só foram retomados em 1946, com a criação da Comissão Técnica de Estudos de Localização da Nova Capital pelo presidente Eurico Gaspar Dutra, cujo chefe foi Djalma Poli Coelho. Após dois anos de estudo, essa comissão reforçou a escolha da área indicada pela Missão Cruls. Somente ao final de 1952, o Congresso Nacional aprova a lei que prevê a realização dos estudos definitivos para a escolha do local no Planalto Central para onde iria a nova capital.

Os estudos foram concluídos em 1955, quando o local escolhido foi aprovado por Café Filho. Em um comício na pequena cidade de Jataí, Goiás, o então candidato à presidência da República Juscelino Kubtschek, responde a uma pergunta feita por um eleitor presente ao ato e ali mesmo promete a todos que, se eleito, transferiria a capital para o Planalto Central. Juscelino apenas confirma aquilo que já vinha sendo organizado há décadas (Brasília: A Capital da Esperança,1980).

Em 31 de janeiro de 1956, Juscelino Kubtschek de Oliveira assume a presidência da república e, em abril, assina a famosa mensagem, acompanhada de Projeto de Lei (transformado na Lei no 2.874 em 19 de setembro de 1956) que delimitava a área do Distrito Federal no planalto, criando também a Companhia Urbanizadora da Nova Capital - NOVACAP (Enciclopédia Mirador, v.4, p. 17881789).

Foi então, realizado o concurso para o projeto do Plano Piloto de Brasília, elaborado pela Comissão de Planejamento da Construção e Mudança da Capital Federal. 
O urbanista Lúcio Costa teve seu projeto aprovado em primeiro lugar, entre os 25 projetos apresentados. Em seu relatório do Plano Piloto, ele cita como nasceu e definiu-se seu projeto. Eis alguns trechos referentes a esse "nascimento" e à área do Lago e destinação de sua orla:

1 - Nasceu do gesto primário de quem assinala um lugar ou dele toma posse: dois eixos cruzando-se em ângulo reto, ou seja, o próprio sinal da cruz;

2 - procurou-se depois a adaptação à topografia local, ao escoamento natural das águas, à melhor orientação, arqueando-se um dos eixos a fim de contê-lo no triângulo eqüilátero que define a área urbanizada;

20 - evitou-se a localização dos bairros residenciais na orla da lagoa, a fim de preservá-la intacta, tratada com bosques e campos de feição naturalista e rústica para os passeios e amenidades bucólicas de toda a população urbana. Apenas os clubes esportivos, os restaurantes, os lugares de recreio, os balneários e núcleos de pesca poderão chegar à beira d'água. O Clube de Golf situou-se na extremidade leste, contíguo à residência e ao hotel, ambos em construção, e o Yatch Club na enseada vizinha, entremeados por denso bosque que se estende até a margem da represa bordejada nesse trecho pela alameda de contorno que intermitentemente se desprende da sua orla para embrenhar-se pelo campo que se pretende eventualmente florido e manchado de arvoredo. Essa estrada se articula ao eixo rodoviário e também à pista autônoma de acesso direto do aeroporto ao centro cívico, por onde entrarão na cidade, os visitantes e ilustres, podendo a respectiva saída processarse, com vantagem, pelo próprio eixo rodoviário-residencial. Propõe-se, ainda, a localização do aeroporto definitivo na área interna da represa, a fim de evitar-Ihe a travessia ou o contorno (Costa, Lúcio. Brasília, cidade que inventei. Relatório do Plano Piloto de Brasília, p. 12, 20, 30).

E assim nasceu a Nova Capital do Brasil: Brasília. 


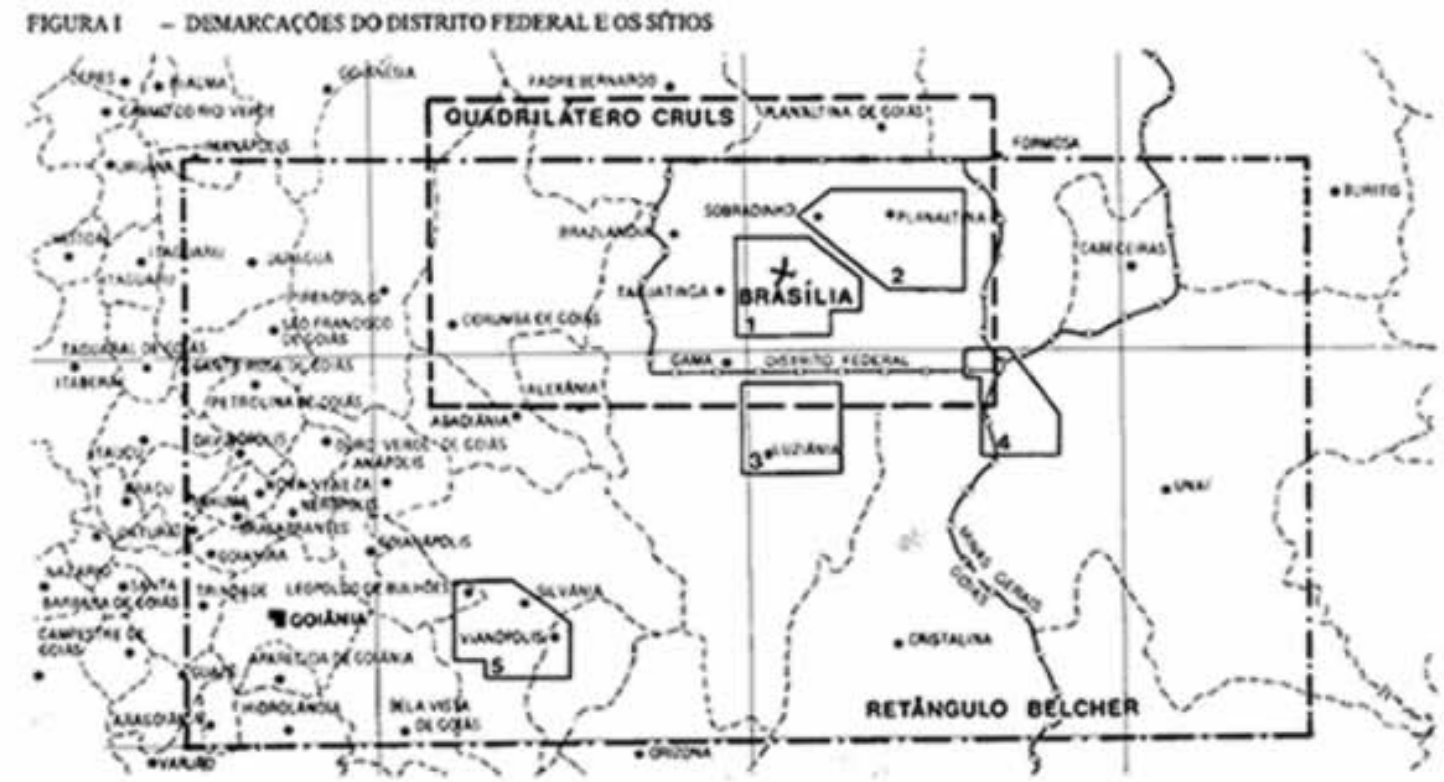
IEGRDA

1 - Sfio Castanks

2 - Strio Verde

3-Sitio Ana

4 - Sitio Vennelo

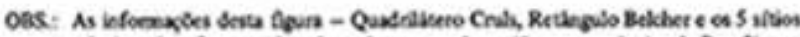
selecionados, foram colocads nobro mapa da roviso pooceobleica le Brastia, ea excala de 1:1. 800000 , dabocado en 1979, peta Codeptas

S - Sitio Amarklo

Quadrilátero Cruls, área retangular que recebeu, oficialmente e pela primeira vez, a expressăo "Distrito Federal".

Fonte: www.semarh.df.gov.br/site/cap02/02.htm 


\section{O Surgimento do Lago Paranoá}

\subsection{Dados Históricos}

A primeira referência sobre a criação do Lago Paranoá surgiu durante a Missão Cruls, em 1893. Em 1953, Café Filho cria a nova Comissão de Localização da Nova Capital Federal, cujo diretor foi Aguinaldo Caiado de Castro, substituído após pelo marechal José Pessoa. Essa Comissão fez os primeiros registros oficiais apontando para a criação de um lago artificial, a fim de compor a paisagem da nova capital. Dentre os trabalhos realizados por ela, destaca-se o relatório feito pela firma americana Donaldo Belcher \& Associates. Conhecido como "Relatório Belcher", ele chama a atenção para o potencial hídrico da região, principalmente, do Rio Paranoá, que mais tarde daria nome ao lago.

Os trabalhos abrangeram a análise criteriosa do clima da região, sua topografia, a paisagem, a constituição do solo e sua drenagem, as facilidades de abastecimento de água e, principalmente, energia elétrica e material de construção. Dentre todos esses aspectos os mais preponderantes para a escolha do melhor local foram o clima e a hidrografia (Relatório Belcher, p. 28 e 29).

Para formar o lago, a Subcomissão de Planejamento Urbanístico da Nova Capital, constituída pelos professores Raul Pena Firma, Roberto Lacombe e José de Oliveira Reis, percebeu que seria necessária a construção de uma barragem no Rio Paranoá. O Memorial Preliminar dos estudos produzidos justificava assim a existência do lago:

Projetou-se uma barragem a jusante do rio, que o transforma num lago ornamental, destinado aos esportes náuticos, limitado pelas margens dos rio Bananal e Gama, transformadas em praias artificiais, cobertas 
por buritizal, numa extensão aproximadamente de $10 \mathrm{Km}$, obtendo-se este motivo paisagístico de encantadora apreciação, que forma com os parques naturais, a serem protegidos, uma agradável atração para a cidade (Silva, Ernesto. História de Brasília, p. 305-6).

No Edital para o concurso do Plano Urbanístico de Brasília, constava que os concorrentes deveriam também propor soluções que previssem o abastecimento de água e energia elétrica, bem como outros serviços básicos à população e à melhoria da umidade do ar, que era muito baixa na região. A existência de um lago artificial circundando a cidade era um ponto comum a todos os projetos apresentados no concurso nacional para a criação da Nova Capital. A sua função também era paisagística, pois estava proposto como elemento urbano da cidade.

A construção da cidade e, em especial, a construção da barragem, não só introduziu modificações na paisagem da região, nos hábitos, tradições e identidade das populações existentes, como também "acirrou o processo de fragmentação da terra e trouxe tecnologias que nem sempre foram adequadas ao ritmo de vida dessas mesmas populações" (Sinoto, M.L., 1988). Por outro lado, colocou-as em contato com algumas facilidades, como serviço médico e escolas disponibilizadas no acampamento, que antes só estavam disponíveis em Planaltina.

As primeiras iniciativas para a construção da barragem que daria origem ao Lago são do final de 1956, com o início do processo de represamento do Rio Paranoá. Ele era formado por rios, córregos e nascentes que o alimentavam e que formavam a Bacia do Paranoá. A NOVACAP montou um acampamento para abrigar os operários e engenheiros das empresas encarregadas da construção da barragem. À medida que as obras avançavam, tornou-se necessário transferir o acampamento para um local mais alto que, posteriormente, ficou conhecido como Vila Paranoá e deu origem à cidade do Paranoá (Secretaria de Educação e Cultura, Brasília, s/d). 


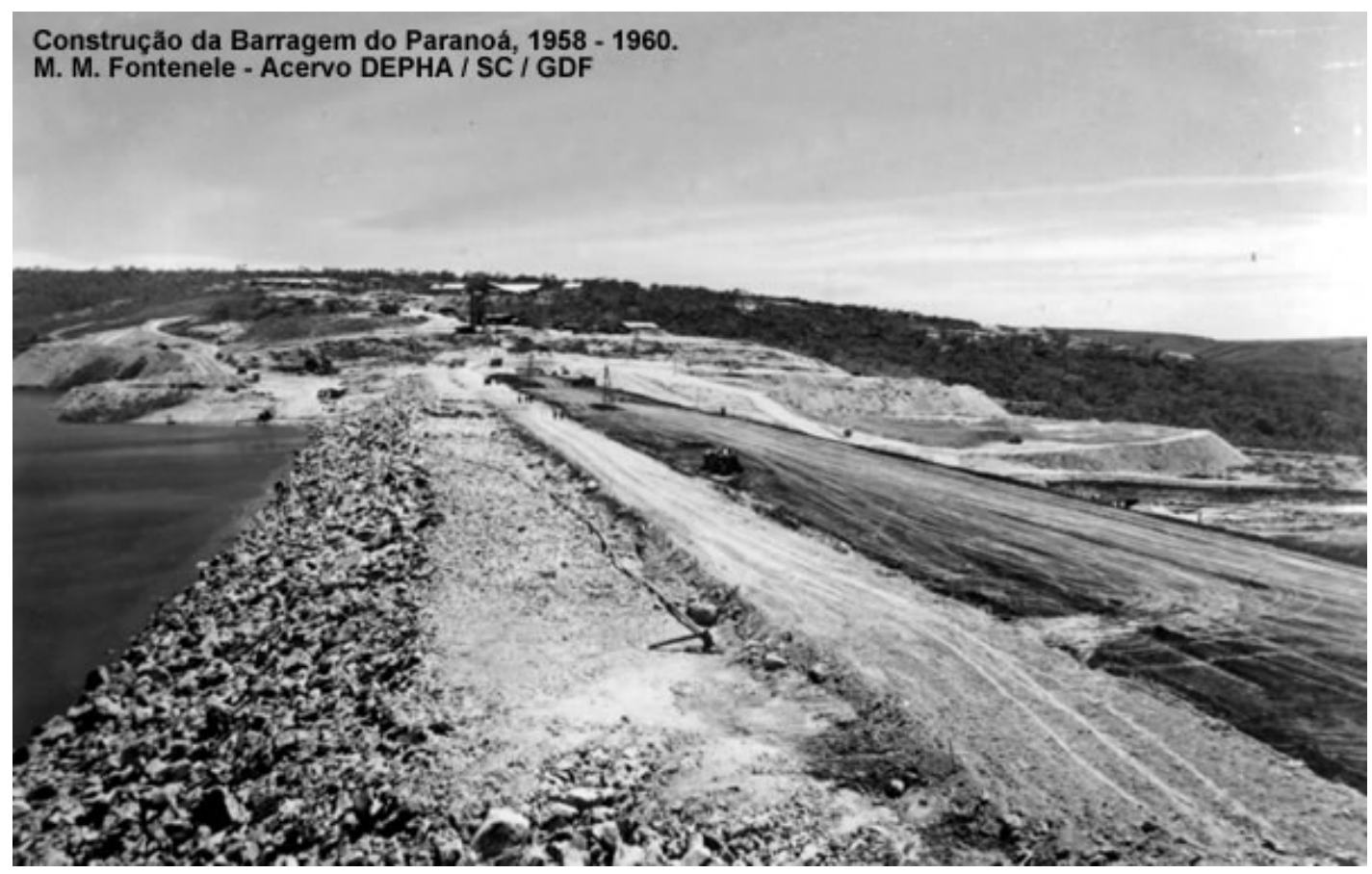

Fonte: www.semarh.df.gov.br/site/cap02/06.htm

Mesmo sendo uma das grandes obras da cidade à época, a Barragem do Paranoá, como obra de engenharia civil, é considerada de pequeno porte. Todos os rios que compõem a Bacia do Paranoá nascem e tem seu trajeto dentro do Distrito Federal, por isso é uma bacia totalmente brasiliense. Ao fechar a comporta da barragem, o presidente Juscelino Kubitschek deu início a inundação do vale previamente desmatado, iniciando também a expulsão dos moradores da Sacolândia, um grande aglomerado de barracos construídos com sacos de cimento vazios, dentro do leito do futuro lago.

Como resultado, o lago quase envolve a capital em um abraço de 40 quilômetros de extensão, de uma ponta a outra, com 60 milhões de metros cúbicos de água. Chega a ter 40 metros de profundidade e está a mil metros acima do nível do mar, com uma extensão maior que a Baía de Guanabara, no Rio de Janeiro. 


\subsection{Aspectos Ambientais}

Apesar de o Lago Paranoá abrigar as Áreas de Preservação Ambiental APAS do Paranoá, cujo objetivo básico é proteger a diversidade biológica, disciplinar o processo de ocupação e assegurar a sustentabilidade do uso dos recursos naturais, vem sofrendo um forte processo de aglomeração urbana, que modifica a paisagem natural, provocando, assim, mudanças no uso do solo e poluem as bacias hidrográficas que drenam a água para o lago, causando crescente degradação na sua qualidade ambiental.

As matas ciliares que protegem os onze córregos que abastecem o Lago Paranoá estão sofrendo um processo de devastação sem precedentes, colocando em risco a sua sustentabilidade, principalmente, para as gerações futuras. Esse aumento populacional verificado na sua área de drenagem vem provocando um crescente lançamento de esgotos e resíduos industriais sem adequado tratamento, além de aumentar o escoamento superficial, causando contaminações, eutroficação ${ }^{1}$, turbidez da água e assoreamento ${ }^{2}$,especialmente junto à foz do Riacho Fundo, do Ribeirão do Torto e do Ribeirão Bananal.

Com a diminuição da captura de tilápias ao longo dos últimos anos, o Lago Paranoá vem apresentando uma elevada biomassa dessa qualidade de peixe, que está sendo responsável pela alta concentração de fósforo na água, promovendo a proliferação das algas (processo de eutroficação) e, conseqüentemente, comprometendo o nível de qualidade da água. A superpopulação desse peixe associada a alterações ambientais, esgota a quantidade de oxigênio da água, provocando alta mortandade de peixes como a que ocorreu na área correspondente à porção inicial do Braço do Riacho Fundo até a Ponte Presidente Médici, também conhecida como Ponte das Garças, que

\footnotetext{
${ }^{1}$ Aumento excessivo de nutrientes na água, especialmente fosfato e nitrato, o que provoca o crescimento exagerado de certos organismos - comumente chamados de algas - e gera efeitos secundários, danosos a outros organismos.

${ }^{2}$ Obstrução, por areia ou por sedimentos quaisquer, de um rio, canal ou estuário, geralmente em conseqüência de redução de correnteza.
} 
liga o Centro Comercial Gilberto Salomão à Asa Sul, em fevereiro de 1998, acarretando transtornos não só à população em geral mas, principalmente, aos moradores mais próximos àquela área.

A boa qualidade da água é de fundamental importância para a prática de atividades náuticas, de lazer e recreação, e seu tratamento é imprescindível para inexistência de odores e contaminação de qualquer espécie. Nesse particular, assume vital importância o controle do desenvolvimento de algas pela redução da disponibilidade de nutrientes.

Saliente-se que a poluição do Lago Paranoá dá-se, em conseqüência da poluição orgânica causada pelo esgoto sanitário derramado em suas águas. A CAESB - Companhia de Saneamento do Distrito Federal executa um programa de observação e avaliação das características limnológicas do Lago Paranoá, contínuo e sistemático. Além dessa observação e avaliação, a CAESB mantém também um outro programa que estabelece, com base na Resolução no 020 do CONAMA, as áreas do Lago que estão próprias para a recreação e o lazer, dados que são repassados à população semanalmente pela imprensa e pela internet.

A CAESB desenvolve ainda um programa permanente para a detecção a ligações clandestinas de esgotos a fim de garantir que todo o esgoto gerado pela população, conseqüentemente, agride o meio ambiente, seja conduzido diretamente às Estações de Tratamento (SILVA et al, 1998).

\subsection{Despoluição do Lago Paranoá}

Muitos lagos que se localizam em áreas urbanas e sofrem influências de enorme massa populacional apresentam sinais de envelhecimento precoce do ecossistema devido às ações do homem. O desenvolvimento desenfreado de alguns tipos de vegetais aquáticos, algas do grupo das verde-azuladas 
(cianobactérias), tem sido uma das causas mais marcante deste processo. No Lago Paranoá o fenômeno não é diferente.

A partir de 1970, com a implantação do Plano Diretor de Água, Esgoto e Controle da Poluição Hídrica do Distrito Federal e com a elaboração do Programa de Recuperação do Lago Paranoá em 1975, teve início o processo de despoluição do Lago.

Mesmo após o início do processo, em 1978, o Lago Paranoá apresentou o florescimento de grande quantidade de algas que fez com que a cidade de Brasília cheirasse mal por cerca de dez dias. Esse acidente ecológico exigiu a aplicação de elevados recursos financeiros para a ampliação e modernização das antigas Estações de Tratamento de Esgotos Norte e Sul de Brasília, e o tratamento de todo os esgotos produzido e remoção de nutrientes, visando permitir que o próprio ecossistema do lago tivesse condições de recompor as suas condições originais.

O aguapé é a macrofilia ${ }^{3}$ aquática mais abundante encontrada no Lago Paranoá. É uma planta emersa e flutuante, nativa da região amazônica que apresenta alta taxa de crescimento (ESTEVES, 1998). Essa espécie prolifera rapidamente em lagos com elevada concentração de nutrientes, que a planta utiliza para o seu metabolismo. Além de absorver esses nutrientes, o aguapé tem a capacidade de remover metais pesados e outros contaminadores da água. Contudo, durante o período de envelhecimento da planta, os nutrientes e metais pesados são liberados para o meio novamente. Assim, as plantas devem ser removidas antes de entrarem nessa fase e esse procedimento é necessário, também, para evitar que as plantas se tornem um problema para o uso recreacional ou na geração de energia elétrica.

Dentro do Programa de Despoluição do Lago Paranoá, a CAESB possui um Projeto de Biomanipulação onde o biólogo Fernando Starling (1998) verificou, através de experimentos em laboratório e "in situ", que a introdução da carpa

\footnotetext{
${ }^{3}$ Diz-se do vegetal dotado de grandes folhas; longifólio.
} 
prateada Hipophthlmicthys molitrix, como forma de controle biológico das cianobactérias em substituição ao emprego do produto químico (sulfato de cobre) e a redução de Tilápias oreochromis niloticus e Tilapia rendalis, contribuem para a melhoria na qualidade da água. $O$ autor verificou que um estoque de carpa prateada de 40 a $50 \mathrm{~g} / \mathrm{m}^{3}$ e uma redução do estoque de tilápias de $100 \mathrm{~g} / \mathrm{m}^{3}$ para $40 / \mathrm{m}^{3}$ induz um decréscimo de fósforo na amplitude de 40 a $44 \%$ e uma redução na biomassa de fitoplâncton de 22 a 38\%. Se as duas medidas forem isoladas, sua combinação reduz o fósforo total em $38 \%$, a densidade de cianobactérias em $75 \%$ e a biomassa de fitoplâncton em $60 \%$.

Mas a recuperação total do Lago Paranoá ocorreu, definitivamente, quando entraram em operação as ETEs Sul e Norte em 1993 e 1994, com tratamento terciário do esgotamento sanitário e várias outras obras, tais como a interligação às novas estações do sistema coletor do Guará I e II, Núcleo Bandeirante e a construção das travessias subaquáticas para os setores habitacionais do Lago Sul e Norte.

Os programas da CAESB de acompanhamento da qualidade da água do Lago Paranoá têm aferido diariamente a sua balneabilidade. Em 1966, esse índice era de $58 \%$, hoje supera os $92 \%$. As concentrações de fósforo total e do nitrogênio foram reduzidas drasticamente, impedindo o aparecimento de algas e um novo desastre ecológico, como o ocorrido em 1978. Paralelamente, a CAESB faz a remoção de aguapés e estudos sobre o peixamento do Lago, com vistas a retirar o excedente da população de tilápias e aumentar o número de carpas prateadas. Essas medidas fazem parte da biomanipulação do Lago Paranoá, citada anteriormente, para a melhoria da qualidade de sua água, tornando-o um ponto de lazer e atividades esportivas disponível à população do Distrito Federal. 


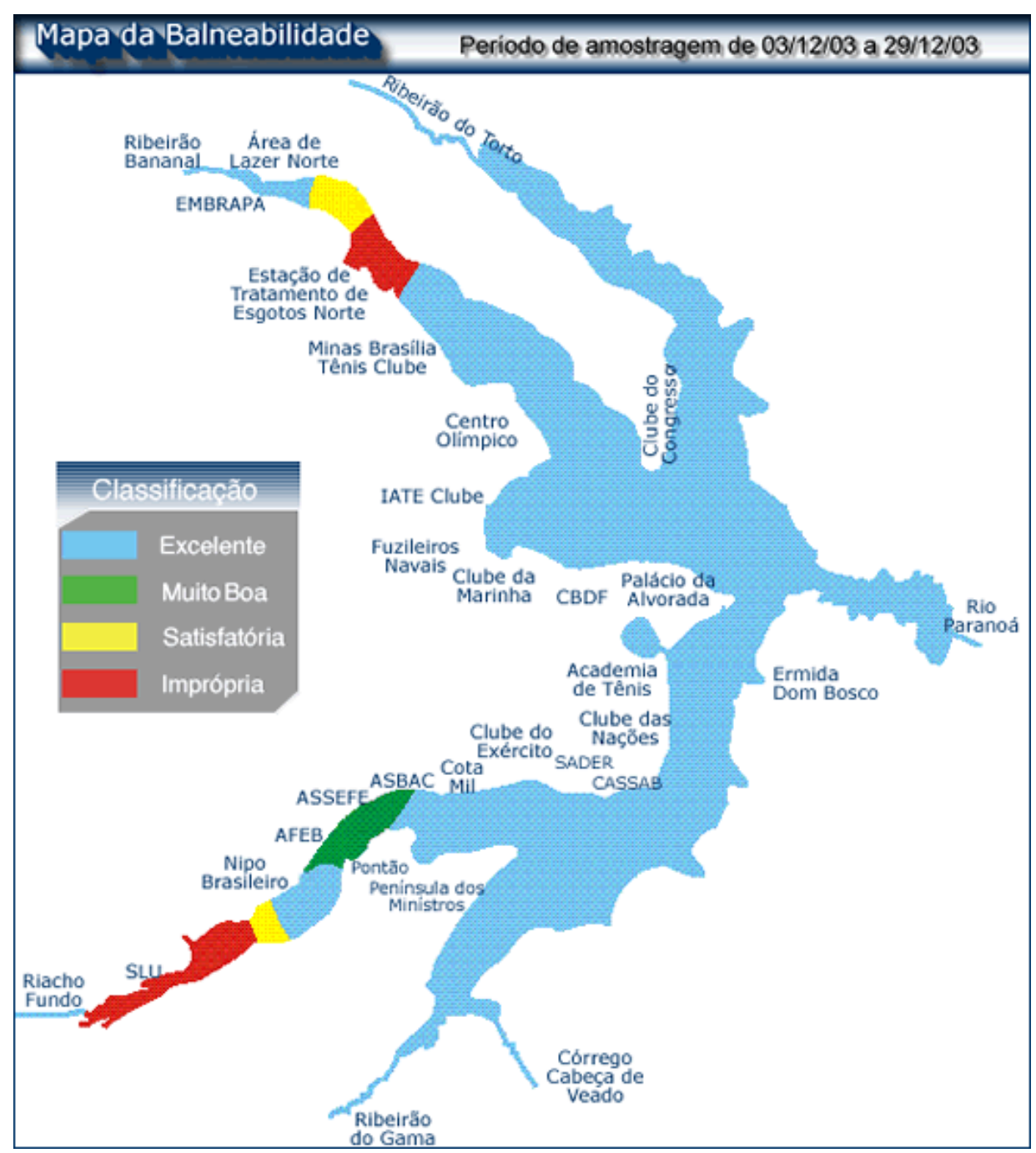

Fonte: www.caesb.df.gov.br/scripts/quali.asp

\subsection{Peixamento do Lago Paranoá}

O Lago Paranoá é excelente local para a prática da pesca amadora, em Brasília; porém muito pouco se tem feito para fomentar essa prática em suas águas. O desenvolvimento da pesca esportiva no Lago Paranoá, hoje, totalmente despoluído e com 92\% de balneabilidade, proporcionará à Brasília uma série de benefícios. Geram emprego e renda para a população através da comercialização de materiais e insumos ligados ao esporte, além da realização de campeonatos e torneios que tem por finalidade: 
$>$ divulgar o potencial turístico do Distrito Federal;

D promover o lazer e a confraternização entre os amantes da pesca esportiva;

desenvolver a consciência ecológica do turista, através da divulgação e prática da legislação específica à atividade da pesca amadora no Brasil, visando combater o uso de materiais e atitudes poluentes e predatórias, na busca de um turismo sustentável com a conservação do meio ambiente, da cultura e tradições da população local;

despertar e sensibilizar as autoridades, tanto no âmbito Federal, como no âmbito Estadual e Distrital, para a normatização específica para o seguimento da pesca esportiva;

estimular e incentivar o desenvolvimento das atividades náuticas e eventos desportivos para o Lago Paranoá.

Em virtude desse grande potencial, foi criado pelo Ministério do Esporte e Turismo (EMBRATUR) e pelo Ministério do Meio Ambiente (IBAMA), o Programa Nacional de Desenvolvimento da Pesca Amadora - PNPA, que objetiva transformar a atividade em instrumento de desenvolvimento econômico e de conservação ambiental.

Conforme pesquisa feita na Secretaria de Turismo do Distrito Federal SETUR, o projeto PEIXAMENTO DO LAGO - "Pescar no Lago" é hoje o projeto prioritário para incrementar o turismo na cidade. Para isso, a SETUR está buscando parceiros para que possa viabilizá-lo e, assim, aumentar o potencial de lazer do Lago Paranoá.

O Deputado Leonardo Prudente, líder do PMDB na Câmara Legislativa, quer trazer para Brasília, turistas e praticantes de esportes aquáticos, que gerariam emprego e melhoria da renda para a população. Para isso, apresentou o Projeto 
de Lei no 675/2003 que propõe a criação do PESCANDANGO - Programa de Peixamento do Lago Paranoá. O objetivo é gerar equilíbrio ambiental do Lago, de suas margens e nascentes, o projeto prevê o povoamento no Lago Paranoá com espécies de peixes consideradas "nobres", como o Tucunaré e o Dourado.

Leonardo Prudente já mostrava a sua preocupação com o Lago Paranoá em seu primeiro mandato, quando apresentou o Projeto de Lei no 2.494/2002. Dispôsse sobre a criação do Gerenciamento Costeiro, visando transformar o Lago em um local de recreação para a população com um forte atrativo à criação de oportunidades turísticas geradoras de renda. Segundo esse Projeto, haveria a definição de um órgão a ser responsável por todas as atividades do Lago.

Para o Deputado, o Lago Paranoá, um dos cartões postais da Capital Federal, é hoje uma das mais importantes áreas de Brasília para seu desenvolvimento turístico. Entretanto, têm recebido pouca atenção dos órgãos públicos para transformá-lo em área de lazer, encontros esportivos, regatas e grandes festas. Ele diz ainda que as tentativas feitas até agora para aproveitar o potencial de atração turística daquela área, têm sido dispersas e descontinuadas.

O "Pescandango" vai buscar um ponto de equilíbrio entre as atividades econômicas e o uso adequado, racional e responsável dos recursos naturais. "Vamos povoar o Lago Paranoá com peixes de espécies nobres, já adultos e compatíveis com a ecologia dos lugares, como o dourado, o matrinchã, o surubim, o tucunaré e, então, promover festivais de pesca esportiva, trazendo pescadores, profissionais e amadores de todo o país. Queremos fazer eventos musicais e teatrais, competições das mais diversas modalidades esportivas aquáticas, tudo de maneira ordenada e com a participação dos órgãos de defesa do meio ambiente. Queremos movimentar o Lago Paranoá, que hoje só é aproveitado pela elite da sociedade brasiliense", disse Leonardo Prudente. 


\section{O Turismo}

Segundo a Organização Mundial de Turismo (OMT,1998), o turismo é uma atividade econômica representada pelo conjunto de transações - compra e venda de serviços turísticos - efetuadas entre os agentes econômicos do turismo. É gerado pelo deslocamento voluntário e temporário de pessoas para fora dos limites da área ou região em que têm residência fixa, por qualquer motivo, excetuando-se o de exercer alguma atividade remunerada no local que visita.

A indústria do turismo gera empregos, aumenta a renda e a entrada de divisas estrangeiras, estimula o investimento de capital e gera oportunidades para a criação de pequenos e grandes negócios. Estimula também a ligação da política e economia local, regional, nacional e global.

De acordo com o PLANO ESTRATÉGICO DE DESENVOLVIMENTO DO TURISMO NO DISTRITO FEDERAL (1999), como atividade econômica internacinal, o turismo representa uma participação direta no Produto Interno Bruto (PIB) mundial de 3 a 4\%. Incluída a participação indireta, a representatividade é superior a $11 \%$ e captura $11,4 \%$ dos investimentos globais de todas as atividades produtivas.

Como se sabe, os produtos turísticos são constituídos por um amplo e diversificado conjunto de atividades econômicas, articuladas entre si, para atender às necessidades de transporte, hospedagem, alimentação, entretenimento e lazer dos viajantes. Totalizam, mais de 52 segmentos da economia com reflexos consideráveis, diretos e indiretos, sobre a geração de empregos. Em razão disso, é acentuada a dinamicidade do setor. Os investimentos requeridos para a criação de um emprego no setor de turismo são muito inferiores aos de outros setores. Movimenta U\$3,4 milhões, empregando 260 milhões de pessoas, o que equivale 
aa $9 \%$ dos postos de trabalho. Essa relação chega a $17 \%$ dos empregos existentes (OMT, 1999).

O turismo não é, necessariamente, desejável e viável em todas as localidades. Cada comunidade deve verificar se dispõe de recursos adequados para desenvolver o turismo e se existem turistas potenciais, suscetíveis de serem atraídos pela localidade. Deve ser analisado se a comunidade precisa do turismo para atingir os seus objetivos de desenvolvimento econômico, dispõe-se de mãode-obra suficiente e capacitada para suportar o atendimento ao turista sem recorrer à migração e, se as verbas necessárias para a melhoria ou construção de acessos à região e respectiva infra-estrutura se justificam.

\subsection{O Turismo Sustentável}

Para ter sucesso com o turismo a comunidade tem que planejar e gerir suas ações de modo a melhorar a qualidade de vida dos residentes, protegendo o ambiente natural e a cultura local. A proteção ambiental é indispensável para o sucesso do desenvolvimento de uma atividade turística. Para tanto, é necessário desenvolver um turismo sustentável, ou seja, racionalizando o uso, conservando e protegendo os recursos naturais, ambientais e culturais, em harmonia com a sobrevivência humana e o bem-estar social, visando não apenas este momento presente, mas, principalmente, as gerações futuras, satisfazendo as necessidades econômicas, sociais e estéticas; mantendo, simultaneamente, a integridade cultural e ecológica. É benéfico para os anfitriões e para os visitantes, enquanto protege e melhora a oportunidade para o futuro (MENEZES, 1999).

Contudo, o desenvolvimento do turismo sustentável também envolve a tomada de medidas políticas vigorosas, baseadas em trocas complexas em nível social, econômico e ambiental (EMBRATUR, 2000). Requer uma visão que abranja maior tempo e espaço do que aquele que é tradicionalmente usado ao 
planejar e tomar decisões relacionadas com a comunidade que envolve os diversos tipos de desenvolvimento do turismo.

A partir do singelo desejo do Lago Paranoá estar saudável, há lançamentos e trocas de olhares de natureza e dimensões diversas, de maneira que essas abordagens, em todos os momentos, foram permeadas por aspectos relacionados com o conceito de sustentabilidade.

Por outro lado, o fato de o lago integrar uma bacia hidrográfica com usos predominantemente urbanos fez com que os enfoques fossem pautados segundo a ótica de que a sustentabilidade do corpo hídrico equivaleria à própria sustentabilidade das cidades que ocupam a área de drenagem.

A Agenda 21 Regional objetiva a busca de alternativas de sustentabilidade das cidades do Distrito Federal por intermédio do estudo, formulação e implementação de um Plano de Ação Integrado em conjunto com a comunidade.

O objetivo maior é o de atender a toda a sociedade, em todos os seus interesses, necessidades e motivações, por meio do uso de conhecimentos, experiências, vontades e valores éticos, para que sejam adotadas atitudes e ações individuais e coletivas para a solução dos problemas ambientais, de forma sustentável, no âmbito do Distrito Federal.

Buscar a sustentabilidade da Bacia do Lago Paranoá significa desenvolver, de forma intensa, um programa de educação ambiental nas cidades que fazem parte da sua área de abrangência, levando a comunidade a perceber a relação existente das ações por ela realizadas em seu espaço (córregos, braços de rios, nascentes, etc) com a qualidade das águas do Lago Paranoá, onde podemos influir positivamente com a adoção de novos comportamentos, como por exemplo, o Turismo Náutico (IPDF/GDF, 1999). 


\subsection{O Turismo em Brasília}

A representatividade nacional e internacional de Brasília como centro do poder é suportada por uma infra-estrutura adequada, consolidada e em processo de expansão. Surgiu como um verdadeiro laboratório, não só para a prática de experimentos urbanísticos modernos, mas também como espaço privilegiado no campo da educação, da cultura, da saúde, da agricultura e da cultura, modelo de demonstração da potencialidade brasileira.

Brasília é um destino turístico internacional emergente. O fluxo é de apenas 36.000 turistas internacionais, o que representa $6 \%$ dos 3,5 milhões de visitantes anuais estrangeiros. Esse número representa menos de $1 \%$ dos turistas internacionais do Brasil, o que se deve a vários fatores, tais como a ausência de vôos internacionais, a inexistência do "marketing" de Brasília e a falta de inclusão da cidade em roteiros turísticos.

Segundo o PLANO ESTRATÉGICO DE DESENVOLVIMENTO DO TURISMO NO DISTRITO FEDERAL (1999), dentre as motivações de viagem declaradas pelos turistas que vêm a Brasília, a de maior importância é a do turismo de negócios (62\%), seguido pelo turismo de convenções (14\%), turismo de lazer (4\%). Outros $20 \%$ declaram diversos motivos para o turismo na cidade. A média de gastos dos turistas estrangeiros é de $\mathrm{R} \$ 392,00$, muito superior à do turista brasileiro que gasta por dia, menos da metade deste valor, $\mathrm{R} \$ 145,00$, com uma permanência média de apenas 2,8 dias.

No contexto do turismo doméstico ${ }^{4}$, Brasília desfruta de algumas características destacadas e favoráveis ao desenvolvimento do turismo:

detém o terceiro lugar em movimento de embarque e desembarque entre aeroportos do país;

\footnotetext{
${ }^{4}$ Pessoas que viajam dentro do seu próprio país
} 
$>$ situa-se no epicentro geodésico do território brasileiro, sendo acessível por automóvel, por 45\% da população total do país;

a maior parte da população de Brasília provém de outros estados, recebendo grande número de visitantes, amigos e familiares, que todos os anos deixam seus Estados de origem com destino à capital;

> Brasília é Patrimônio Cultural da Humanidade pelo seu projeto urbanístico arrojado e futurista e por sua arquitetura monumental, destacando-se para o "tour" cívico-cultural (SETUR, 2003). 


\section{Projeto Orla}

No mundo inteiro, as cidades que possuem praias, lagos ou rios fazem de suas margens espaços públicos agradáveis, bem aproveitados e valorizados não só para atrair turistas, mas sobretudo para usufruto de seus habitantes. Em Brasília não é diferente.

O Projeto Orla foi concebido tendo como embrião o Centro de Lazer Beira Lago, projeto proposto pela Companhia Imobiliária de Brasília - TERRACAP, que, à época havia sido escolhido pelo Ministério do Turismo para representar o Brasil no Fórum Internacional de Turismo, realizado em Recife.

Para viabilizar a implantação do Projeto Orla, foi idealizado pela TERRACAP, juntamente com o IPDF, um projeto de parceria entre os setores público e privado. Com o projeto, abrem-se novas e expressivas oportunidades de investimento nos mais variados setores empresariais, pois somente em Brasília, aonde o governo dispõe de instrumentos eficazes de controle do solo, pôde-se pensar em um projeto dessa magnitude, garantindo-se a qualidade de seus espaços.

O Projeto Orla, de 1992, previa a implantação de dez pólos de atividades, com uma área construída estimada em $780.000 \mathrm{~m}^{2}$. Segundo os cálculos da época, o custo total da edificação dos complexos atingiria cerca de U\$390 milhões (de dólares), prevendo-se a necessidade de empregar diretamente nas obras de construção civil, cerca de 166 mil homens/ano. Na operação dos equipamentos implantados com o Projeto, uma estimativa preliminar situava a geração de aproximadamente 30 mil empregos, diretos e indiretos.

O Projeto ganha uma atualização em 1995, passando a ser composto de onze pólos e um calçadão, chamado de "alameda" que os interligam. Nestes 
pólos localizam-se diversas atividades culturais, comerciais e de lazer, além de um complexo hoteleiro. Em cada pólo, permite-se o máximo possível de atividades complementares, possibilitando maior dinâmica e variedade na sua utilização diurna e noturna.

Com isso, o Projeto Orla reaproxima a cidade do Lago Paranoá e o devolve a população, resgatando para Brasília a idéia de Cidade Viva.

Para consolidar essa vocação turística e de lazer extremamente atrativa, procurou-se identificar nos locais de interesse as particularidades a serem ressaltadas, criando espaços diferenciados, ricos e complementares entre si.

\subsection{Pólo 1 - Pontão do Lago Norte}

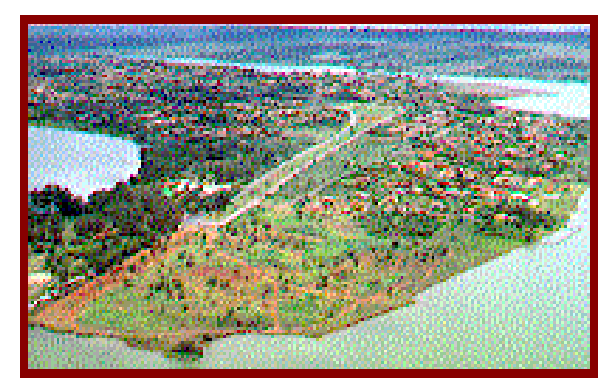

Fonte: www.setur.df.gov.br/Orla1.html

Está situado em uma área de 105.093,59 $\mathrm{m}^{2}$, ao lado do Clube do Congresso. Foi prevista para ali, a localização de marina pública, uma escola de vela, pequenos centros comerciais e áreas para cultura, esporte, lazer e recreação infantil. Esse pólo foi criado para constituir-se no maior centro de lazer da comunidade do Lago Norte, estimada em aproximadamente 15.000 habitantes.

O pólo apresenta projeto urbanístico aprovado pelo Decreto n 18.359/97. 


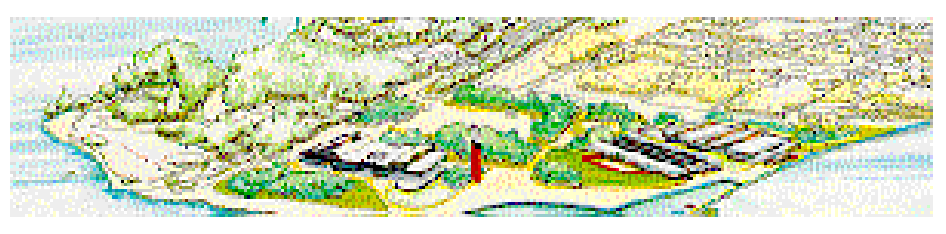

Fonte: www.setur.df.gov.br/Orla1.html

\subsection{Pólo 2 - Complexo da Enseada}

O Complexo da Enseada está situado entre o Clube Almirante Alexandrino e o Clube da Aeronáutica, numa área total de aproximadamente $745.170 \mathrm{~m}^{2}$. Localizam-se neste pólo áreas destinadas à construção de quatro hotéis ou aparthotéis, bem como áreas para restaurantes, bares, quiosques, feiras de antigüidades e artesanato, marinas e ancoradouros.

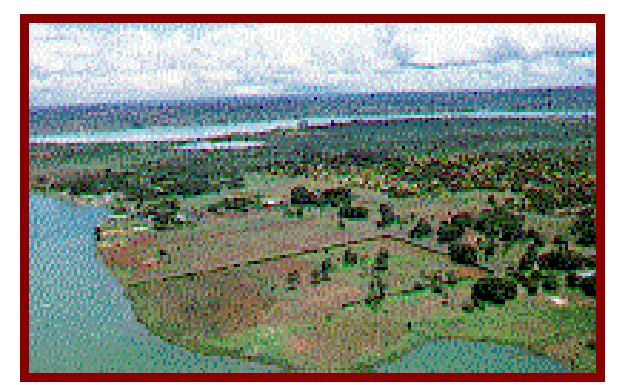

Fonte: www.setur.df.gov.br/fotosOrla.html

Esse pólo apresenta projeto urbanístico aprovado pelo Decreto $n^{0}$ 18.359/97. 


\subsection{Pólo 3 - Complexo Brasília Palace}

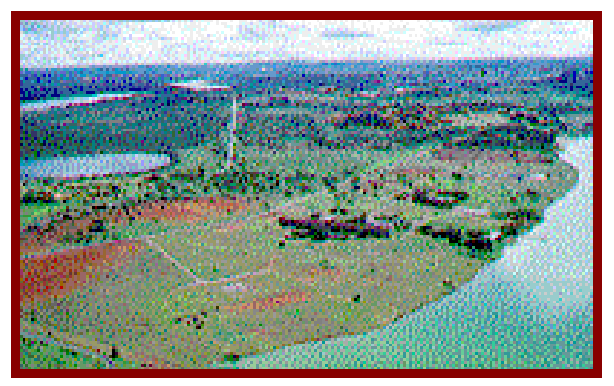

Fonte: www.setur.df.gov.br/Orla2.html

O Complexo Brasília Palace incorpora o Setor de Hotéis de Turismo e a área contígua destinada à recreação pública, abrange aproximadamente $578.592 \mathrm{~m}^{2}$, entre o Clube da Imprensa e o espaço livre próximo ao Palácio da Alvorada, denominado Bosque dos Leões. Possui lotes para quatro hotéis, entre os quais o Brasília Palace, tombado pelo Patrimônio Histórico. Caracteriza-se também como pólo cultural, onde já existe o Museu de Arte de Brasília e a Concha Acústica que, associados aos futuros Pavilhão de Bienal de Arte, constituirão a Praça das Artes. Ainda serão instalados pontos para comércio, bares, restaurantes, cinemas e marinas.

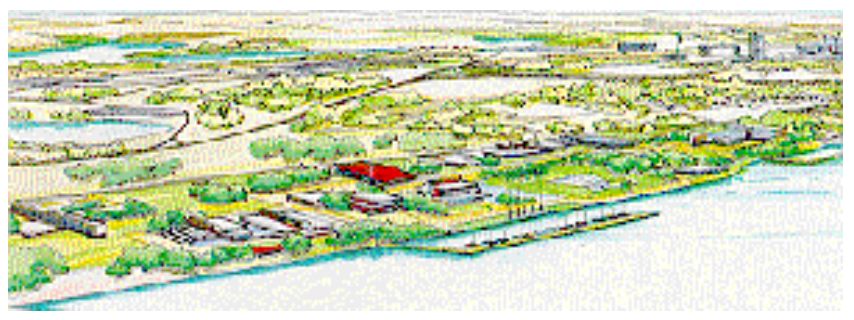

Fonte: www.setur.df.gov.br/Orla2.html

Esse pólo apresenta projeto urbanístico aprovado pela Lei nº 1290/96. 


\subsection{Pólo 4 - Parque do Cerrado}

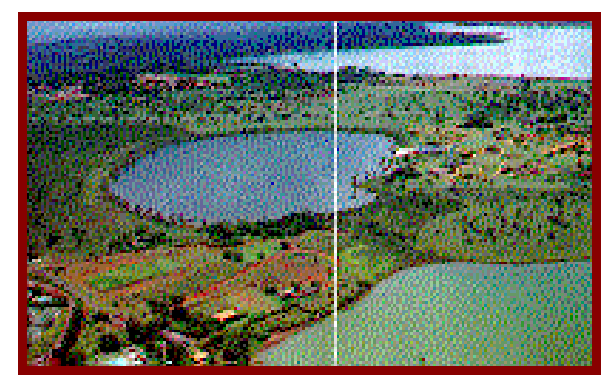

Fonte: www.setur.df.gov.br/Orla3.html

Parque natural de aproximadamente $100.000 \mathrm{~m}^{2}$, área de preservação ecológica, às margens da Lagoa do Jaburu, vizinha à residência do vicepresidente da República. Por meio da alameda haveria uma ligação entre as orlas Norte e Sul, para a construção do Museu do Cerrado, onde os visitantes poderão conhecer aspectos da flora e da fauna do cerrado.

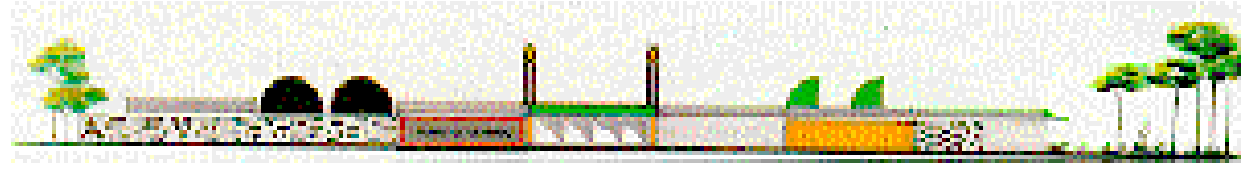

Fonte: www.setur.df.gov.br/Orla3.html

O estudo de remanejamento urbano para instalação do parque, já pronto, depende ainda de posicionamento da Secretaria de Meio Ambiente e Recursos Hídricos - SEMARH. 


\subsection{Pólo 5 - Marina do Paranoá}

Situado entre o Clube das Nações e a Academia de Tênis, tem área de aproximadamente $10.000 \mathrm{~m}^{2}$, destinada à atividade hoteleira, completada por marina pública, bares, restaurantes e comércio de pequeno porte.

\subsection{Pólo 6 - Centro de Lazer Beira Lago}

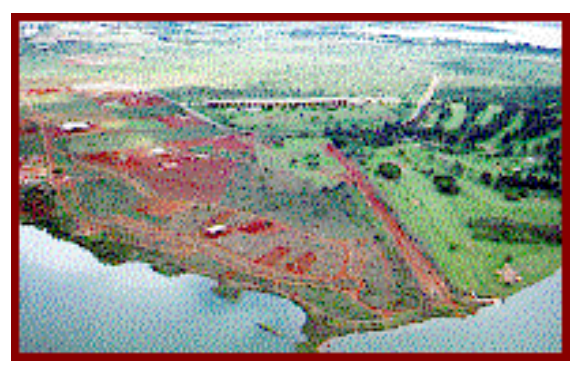

Fonte: www.setur.df.gov.br/Orla4.html

Localizado numa área de aproximadamente $80.000 \mathrm{~m}^{2}$, junto ao acesso da terceira ponte do Lago Sul, o Centro de Lazer Beira Lago destina-se à criação de um centro comercial e de diversões onde poderão ser instalados bares, restaurantes, lojas de conveniência, espaços para arte e cultura, além de uma marina pública.

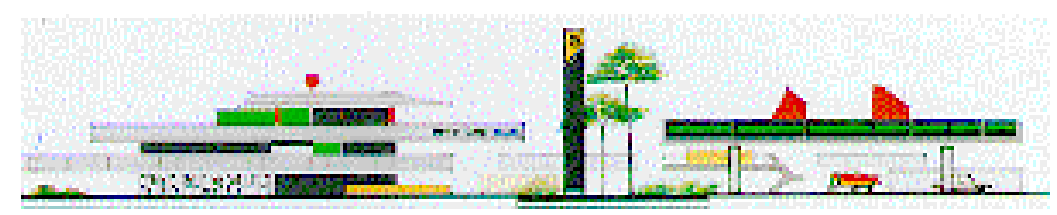

Fonte: www.setur.df.gov.br/Orla4.html 


\subsection{Pólo 7 - Parque Tecnológico}

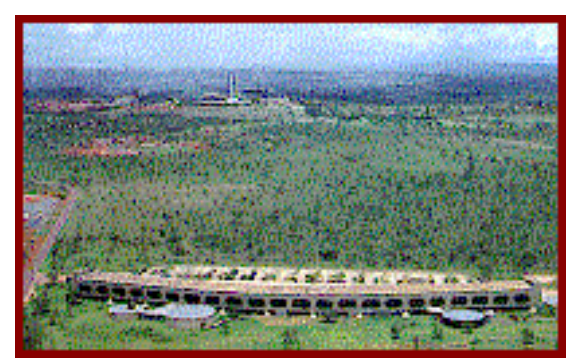

Fonte: www.setur.df.gov.br/Orla5.html

O Parque Tecnológico, situado numa área de 331.517,41 $\mathrm{m}^{2}$, destina-se a abrigar o Museu da Ciência e Tecnologia, onde os equipamentos em exposição poderão ser utilizados pelos visitantes numa relação interativa. Estão previstas áreas para exposições, conferências, além de comércio relativo ao tema ciência e tecnologia.

Esse pólo apresenta projeto urbanístico aprovado pelo Decreto n 19.786/98.

\subsection{Pólo 8 - Centro Internacional}

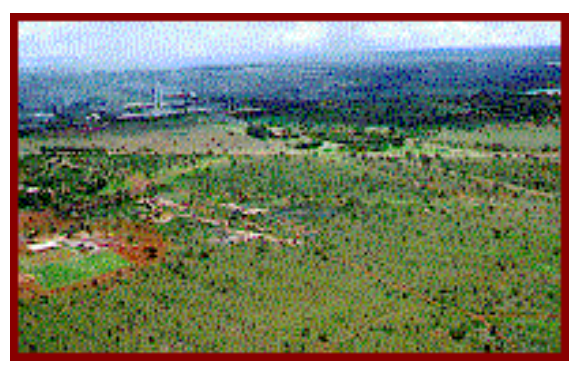

Fonte: www.setur.df.gov.br/Orla6.html

Concebido para abrigar um conjunto de edificações, em uma área verde de $683.059,82 \mathrm{~m}^{2}$, eqüidistante dos Setores de Embaixadas Sul e Norte, o Centro 
Internacional destina-se a Organismos Internacionais. O planejador considerou, igualmente, a proximidade e a facilidade de acesso do mesmo à Esplanada dos Ministérios.

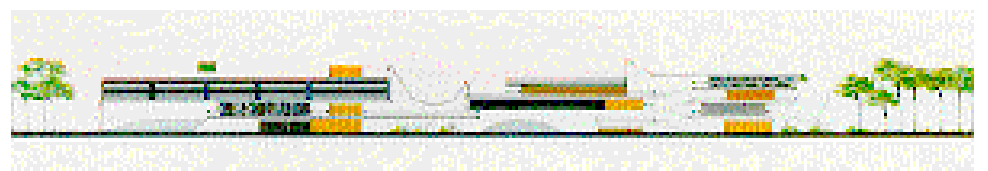

Fonte: www.setur.df.gov.br/Orla6.html

Esse pólo apresenta projeto urbanístico aprovado pelo decreto nº 19.786/98.

\subsection{Pólo 9 - Parque Aquático}

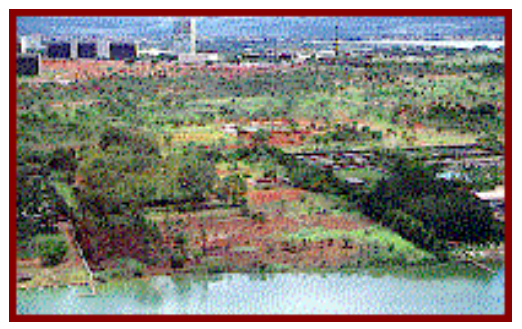

Fonte: www.setur.df.gov.br/Orla7.html

Pólo de Atração Náutica rico em atividades de lazer, com área de aproximadamente $30.000 \mathrm{~m}^{2}$, próximo à Vila Paranoá. O espaço comportaria a implantação de uma pequena marina, assim como comércio ligado à atividade náutica, bem como bares e restaurantes. 


\subsection{Pólo 10 - Praça das Nações}

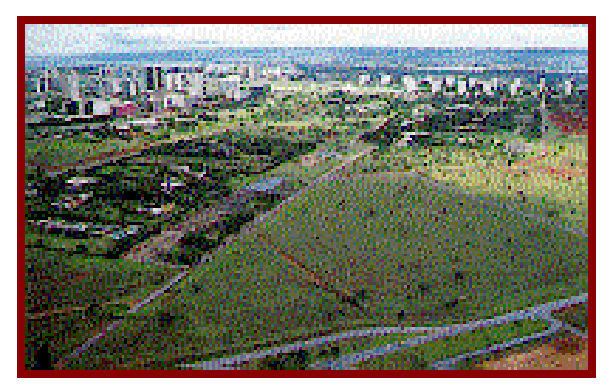

Fonte: www.setur.df.gov.br/Orla8.html

Situado em área de aproximadamente $270.500 \mathrm{~m}^{2}$ a Praça das Nações é um pólo destinado à construção de pequenos pavilhões para mostras de cultura e história dos diferentes países que têm representação diplomática em Brasília. A idéia básica seria a doação das áreas para que as diversas embaixadas construíssem seus pavilhões, de acordo com as modernas tendências arquitetônicas dos seus países.

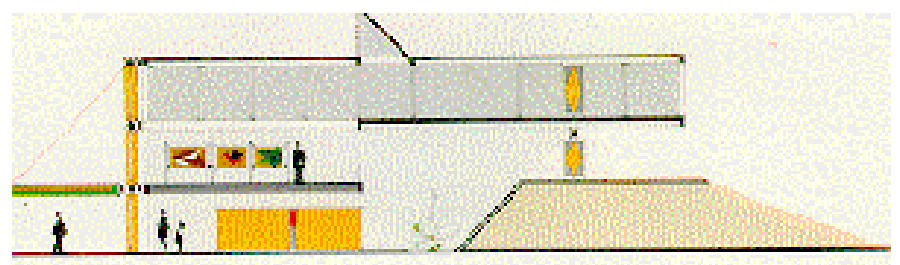

Fonte: www.setur.df.gov.br/Orla8.html

Esse pólo foi indeferido pelo Instituto de Planejamento Histórico, Artístico Nacional - IPHAN, devido ao tombamento pelo patrimônio historio da área que seria destinada a ele. 


\subsection{Pólo 11 - Pontão do Lago Sul}

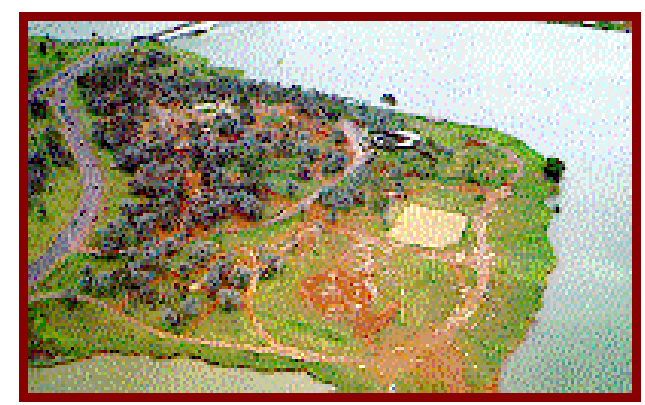

Fonte: www.setur.df.gov.br/Orla9.html

O Pontão do Lago Sul situa-se em área de aproximadamente $110.000 \mathrm{~m}^{2}$, ao final da ponte Costa e Silva no Lago Sul já consagrada como área de lazer, onde foi prevista a implantação de restaurantes, bares, pequeno comércio, feiras de antiquários e artesanatos, equipamentos para esportes, assim como um atracadouro para barcos.

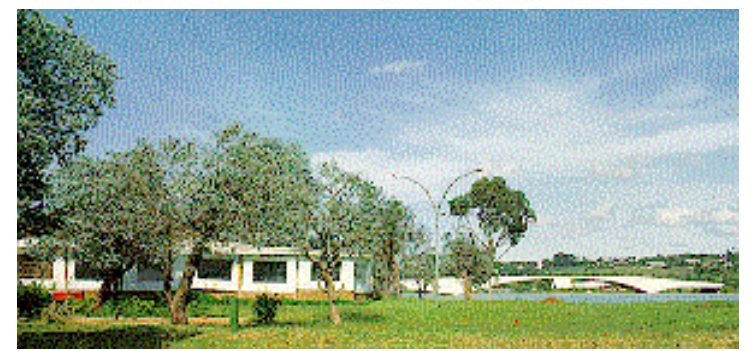

Fonte: www.setur.df.gov.br/Orla9.html

Esse pólo apresenta projeto urbanístico aprovado pelo Decreto $\mathrm{n}^{0} 17.532$ de 18/07/96. 


\section{Considerações Finais}

Com base na análise das entrevistas e na coleta de dados, percebe-se que o turismo no Distrito Federal está completamente apático no que diz respeito ao Lago Paranoá.

Considerando-se a importância da potencialidade que representa o Lago Paranoá no contexto da cidade, seria necessária a elaboração de um Plano de Ocupação ou de um Plano Diretor para a orla do Lago, pautado pela sensibilidade ambiental, para evitar uma intensificação de uso acima da capacidade de suporte das águas e das margens.

Com o objetivo de explorar essas potencialidades, são apontadas algumas diretrizes que trariam resultados a curto e médio prazos. Essas propostas devem ser traduzidas em ações concretas, mediante a parceria dos órgãos governamentais das entidades comunitárias e dos empresários dos setores envolvidos, o que provocaria uma mudança radical na forma de apropriação do Lago.

As atividades de lazer na orla foram objeto de cuidadosa análise que mostrou percepção e as expectativas quanto à prática e permanência dessas atividades. Alguns conflitos foram percebidos por moradores e turistas, evidenciando claramente, a necessidade de uma melhor gestão administrativa.

Nos eventos de esporte náutico, o esportista, ao mesmo tempo em que pode ser espectador e praticante, é igualmente consumidor de serviços e um futuro divulgador da localidade. Durante sua permanência na cidade, usufrui dos serviços e da infra-estrutura como qualquer outro turista ou morador local, porém, com nível de exigência diferenciado, em razão do seu padrão de consumo. 0 resultado positivo ou negativo da experiência desse turista depende, sobretudo, 
das condições de recepção, da hospitalidade e da oferta de atrativos, não apenas naturais, mas também culturais.

Verificou-se que os eventos no Lago Paranoá são, na sua maioria, de iniciativa privada, geralmente, pelos clubes que oferecem modalidades esportivas na sua grade de atividades.

Esses eventos representam boas estratégias de marketing, o que, com certeza, podem contribuir para o incremento e a consolidação do turismo local.

Incluir Brasília no calendário de esportes náuticos aumentaria o fluxo de visitantes e poderia minimizar os efeitos da sazonalidade, promovendo acontecimentos durante todo $\mathrm{o}$ ano.

Dentre as medidas que poderiam ser adotadas, podemos citar:

implantação dos onze pólos do Projeto Orla;

$>$ definição do calendário de eventos culturais e esportivos em torno do Lago;

> divulgação do potencial turístico da cidade, explorando toda a orla do Lago Paranoá;

> implantação dos terminais turísticos e mirantes ao redor do Lago Paranoá;

$>$ promoção da pesca esportiva no Lago;

> construção de marinas públicas; e

promoção de eventos náuticos nacionais e internacionais.

Resta manifestar um desejo: que esta pesquisa ajude no convencimento de que a implementação de um plano diretor para a orla do Lago Paranoá é necessária, inspirando os atores relevantes para o processo a darem início à empreitada, particularmente os governantes, que precisarão, para tanto, de desprendimento, coragem e decisão política para lograrem êxito. 


\section{Entrevistas}

\subsection{Entrevista com o Ex-Secretário de Turismo do DF, Rodrigo Rollemberg}

Como Secretário de Turismo do Governo do Distrito Federal, a partir de 1996, o então Deputado Rodrigo Rollemberg participou ativamente da concepção do Projeto Orla, para melhor aproveitamento da orla do Lago Paranoá: "Foi um projeto que exigiu um tempo de maturação em relação à sua concepção e sobretudo em relação à realização das licitações para aquelas áreas". Segundo Rollemberg, o modelo utilizado foi o da Técnica e Preço em que as empresas vencedoras pagariam uma parcela do seu faturamento ou uma quantia mínima mensal, prevalecendo o maior valor.

A implantação do projeto foi iniciada pelo pólo 3, o Pontão do Lago Sul, totalmente implantado apenas no governo seguinte e de forma um pouco diferenciada da concebida no projeto original. Não havia a previsão nem se permitiria qualquer tipo de cerca limitando o acesso. "Cercas não eram previstas, pois os fundamentos do Projeto Orla eram exatamente democratizar o acesso à orla do Lago para o conjunto da população/comunidade brasiliense e turistas que visitam nossa cidade. Porém, ao longo dos anos a orla do Lago vem sofrendo uma privatização irregular com as "invasões" de terras públicas que "privatizaram" o acesso a orla". De acordo com o ex-secretário, todos os terrenos que foram a licitação têm sua metragem interrompida a uma distância considerável da margem do Lago, o que permite o acesso público ao Lago. Ele enfatiza que o projeto, hoje, não supre as expectativas de quando foi criado, mas, ainda assim, considera o Projeto Orla como o mais importante projeto para o desenvolvimento econômico, 
para o fortalecimento da vocação turística, para a popularização e democratização do lazer e, principalmente para a geração de emprego e oportunidades no Distrito Federal. Ainda considera o Projeto fundamental, mas lamenta que foi abandonado pelo atual governo do Distrito Federal que não deu continuidade à implantação dos demais pólo ao longo de toda orla.

\section{O Pontão do Lago Sul}

"Os freqüentadores do Pontão hoje, são pessoas muito elitizadas. O cercamento daquele espaço inibe as pessoas de menor poder aquisitivo a freqüentá-lo e também o tipo de comércio desenvolvido dentro da área é caro para esta população. Deveriam ser criadas novas áreas, com novos perfis, para a população de baixa renda, com atividades gratuitas, popularizando assim o local", opina Rollemberg.

\section{$\underline{\text { A Ponte JK }}$}

Com relação à Ponte JK, a terceira ponte que liga a Asa Sul ao Lago Sul, Rollemberg é de opinião que contribuiu muito para a valorização do Lago e do Projeto Orla como atividade turística. Para ele, trata-se de uma ponte realmente belíssima e atrai a população local e também o turista visitante, mas acha que o espaço deveria ser "incrementado com quiosques para a população de menor poder aquisitivo".

\section{$\underline{\text { Um lago popular }}$}

Para Rollemberg, o Lago deveria ter em algumas áreas, as características de praia, onde as pessoas pudessem caminhar, namorar, tomar um banho, praticar esportes - os tidos como de praia: vôlei de praia, futivolei, frescobol - ou seja, uma lazer gratuito. Em outras, atividades econômicas mais acessíveis à população como quiosques para uma parada, tomar uma água de coco, um chopinho, comer algo, ouvir uma música ao vivo nos finais de semana, enfim atividades típicas de "beira de praia", que seriam uma alternativa para o entretenimento das populações de renda menos favorecida. "Da forma que está 
não atende a um dos pontos chave do Projeto que é a democratização do lazer no Lago Paranoá", acrescenta Rollemberg.

\section{Água do Lago}

"Com o funcionamento da estação de tratamento Norte-Sul, a água do Lago vem melhorando muito e aumentando a balneabilidade. A água do Lago já é própria para o banho e esportes náuticos na quase totalidade de sua área. É necessário, entretanto, que seja permanentemente monitorado este tratamento, por ser um lago urbano, evitando-se assim, riscos à população".

\section{$\underline{\text { Administrações Regionais }}$}

Rollemberg acha que as Administrações Regionais poderiam incentivar mais o Projeto Orla. Lembra que o pólo 3 ficou deteriorado e o Governo do Distrito Federal teve que refazer todas as obras. Enfatiza a pouca expressão que tem $A$ Secretaria de Turismo, que deveria funcionar como um grande instrumento de defesa do turismo na cidade, mas que no entanto, permanece apática e insipiente.

Ele defende a necessidade urgente de um Plano Diretor para o turismo e, conseqüentemente, um Plano Diretor para o desenvolvimento das margens do Lago, de forma que o crescimento se dê de forma sustentável e com investimentos de qualidade para o total aproveitamento do potencial do Lago Paranoá.

"Termino enfatizando que a população do Distrito Federal, como um todo, tem que ter acesso ao Lago, porque é a forma de lazer mais barata e prazerosa que a comunidade possui. Não vejo interesse no Governo do Distrito Federal em popularizá-lo, até porque está havendo a privatização paulatina da orla do Lago, sem qualquer impedimento", finaliza Rollemberg. 


\subsection{Entrevista com a Secretária de Desenvolvimento Urbano e Habitação - Ivelise Longhi}

Sobre a utilização da orla do Lago Paranoá como área de lazer para a população de Brasília como um todo, a Secretária de Desenvolvimento Urbano e Habitação é de opinião que se deve ampliar o acesso da população à orla e democratizar sua utilização. "Queremos resgatar a vontade daqueles que quase não freqüentam o lago por dificuldade de acesso". Para tanto pretende, proximamente, reunir-se com representantes da comunidade para discutir as formas de ocupação da orla.

Levantamento recente da Secretaria resultou na constatação de que $22 \%$ da orla pertence à TERRACAP. São 219 lotes que poderão ser utilizados para aproveitamento como áreas de lazer. Distribuídos na orla do Lago Paranoá existem 102 clubes, oito restaurantes e cervejarias, onze órgãos institucionais, dez organismos internacionais e seis outras áreas destinadas à cultura. A maioria dos freqüentadores da orla do Lago são sócios de algum clube. Segundo a Secretária deverão ser propostas parcerias com estes clubes a fim de utilizar sua área de lazer com maior aproveitamento por toda a população. 


\section{Discussão dos Resultados}

De acordo com os depoimentos coletados, observamos vários conflitos sobre o Lago Paranoá que relatamos abaixo:

Quando se fala da potencialidade do Lago para as atividades de lazer, fica evidente a falta de um plano diretor para a orla.

Para o Assessor da Comodoria do late Clube de Brasília - Alberto Lasserre Kratzl Filho - "Brasília está deixando capitais litorâneas para trás quando o assunto é navegação. São mais de 1200 embarcações que disputam cada espaço. É a terceira cidade em frota de embarcações, perdendo apenas para Rio e São Paulo".

Jeferson Gazonni - da área de projetos da SETUR - relatou que a secretaria tem participado de algumas feiras náuticas (nacionais e internacionais). Em São Paulo, recentemente, participaram do Bolt-Show, com o intuito de explorar os eventos náuticos.

Já o proprietário do restaurante Lua Nua, situado às margens do Lago Paranoá no morro da Asa Delta no Lago Sul, e do barco de turismo Lua Azul - Sr. Reis - acredita que o grande avanço das atividades de lazer do lago se deve a duas pessoas : ao ex-presidente Collor de Mello, que nos finais de semana desfilava na orla com seu jet-ski, fazendo até algumas manobras radicais, e ao então Secretário de Turismo do Governo do Distrito Federal - Rodrigo Rollemberg - que deu um grande passo ao implantar o Projeto Orla. Reis começou com atividades na orla há 10 anos e enfatiza a necessidade de um plano de gestão para o lago. 
Luís Carlos, diretor da náutica do Minas Brasília Tênis Clube, concorda com Reis - " O potencial do lago é muito maior. O lago é de todos, mas para torná-lo popular só com uma ação do governo. Tentou-se democratizar o acesso ao Paranoá com o projeto orla, mas ele está totalmente parado. Um verdadeiro descaso. Nos clubes, a maioria dos associados são elitizados."

Alberto Kratzl afirma ainda que está longe a possibilidade de o Turismo Náutico em Brasília ser popularizado e, conseqüentemente, aproveitado para geração de empregos e renda. Para Reis, o atual governo não se dispõe a criar ações para popularizar o Lago, como: cuidar do espaço criado para banhistas no Lago Norte, apelidado pela população de "piscinão de ramos", colocar uma marina pública na prainha, que fica localizada próxima a primeira ponte de ligação da Asa Sul ao Lago Sul, para facilitar os passeios de barco e aumentar a infraestrutura dos locais de livre acesso. O professor de remo do Minas Brasília Tênis Clube - Sr. Quati - concorda com Reis. "A coqueluche entre os que não têm acesso a barcos, lanchas e jet-ski era o "piscinão", mas o governo não deu a devida atenção ao local, assim como à prainha que acabaram por ser esquecidos e abandonados pelos brasilienses e pelos turistas. A versão candanga do "piscinão de ramos" tem um problema que espanta os visitantes. Em lugar de areia, a beira do lago está coberta de cascalho. Com o calor ninguém agüenta andar ou deitar sobre o cascalho quente. Falta interesse dos governantes para melhorar o local e até transformá-lo em ponto turístico. Até parece que o governo quer mesmo o Lago elitizado. Na prainha, a falta de estrutura espanta os visitantes. Faltam banheiros, cestos de lixo, quiosques ...

São passeios que contam com a brisa do lago e não cobram entrada dos visitantes, mas visivelmente abandonados. A SETUR e as administrações regionais não querem trazer o "povão" para o Lago."

A Companhia de Saneamento do Distrito Federal (CAESB, 2003) tem feito um ótimo trabalho na despoluição do Lago, aumentando o potencial para o Turismo Náutico, razão pela qual, os clubes da orla têm promovido vários eventos, arcando com total divulgação e responsabilidade na organização. 
Jeferson Gazonni adiantou que o único projeto em andamento atualmente na SETUR é o Peixamento do Lago visando desenvolver a pesca esportiva no Lago Paranoá. "A Pesca no Lago pode trazer um grande fluxo turístico para o DF, uma vez que tira a imagem fria da cidade. Para 2004, vamos abrir a licitação para os quiosques da concha acústica. O local estava destruído, deprimente, abandonado, depredado. Era um ponto turístico digno de ser mostrado aos hóspedes da família brasiliense, aos próprios turistas, à população que ávida por diversão, tinha um local pitoresco para levar as crianças e passar horas de descanso e entretenimento. Tudo foi refeito, restaurado e reformado. Cinco quiosques e dois banheiros estão novinhos, com revestimento em pastilhas coloridas".

A ponte JK pode receber em breve, uma área destinada ao lazer. Formado por um calçadão, um píer e um mirante, o espaço dará a brasilienses e turistas a oportunidade de observar a ponte eleita como a mais bela do mundo. $\mathrm{O}$ arquiteto Alexandre Chan, autor do projeto da JK, deve criar o novo espaço que prevê a construção da Casa do Visitante um ponto de apoio ao turista com informações sobre toda a área. A iniciativa foi divulgada pelo próprio governador do Distrito Federal.

Para o Projeto Orla estamos esperando parcerias de iniciativa privada, por enquanto apenas o Pontão do Lago Sul está a pleno vapor".

Observa-se que o gerenciamento costeiro e a compatibilização dos diversos usos do lago são medidas que deverão ganhar maior importância com a intensificação do uso da orla, tanto para o lazer e o turismo nas margens, quanto para o esporte e a recreação nas suas águas.

Os conflitos entre os usuários do lago vêm-se evidenciando a cada dia como se pôde averiguar na discussão dos resultados, envolvendo os órgãos de saneamento e de energia com os banhistas; pescadores e navegadores; os moradores e os clubes; com o uso privado e os que buscam as áreas públicas para acesso às "praias"; e as embarcações à vela e à remo com as lanchas e os jet-skis. 
Enfim, é evidente a necessidade de estabelecer-se um sistema de gestão do Lago Paranoá, envolvendo os seus múltiplos usuários, para a administração dos diferentes interesses e o ordenamento do uso e ocupação das suas margens e do seu espelho d'água. 


\section{Pontos Turísticos}

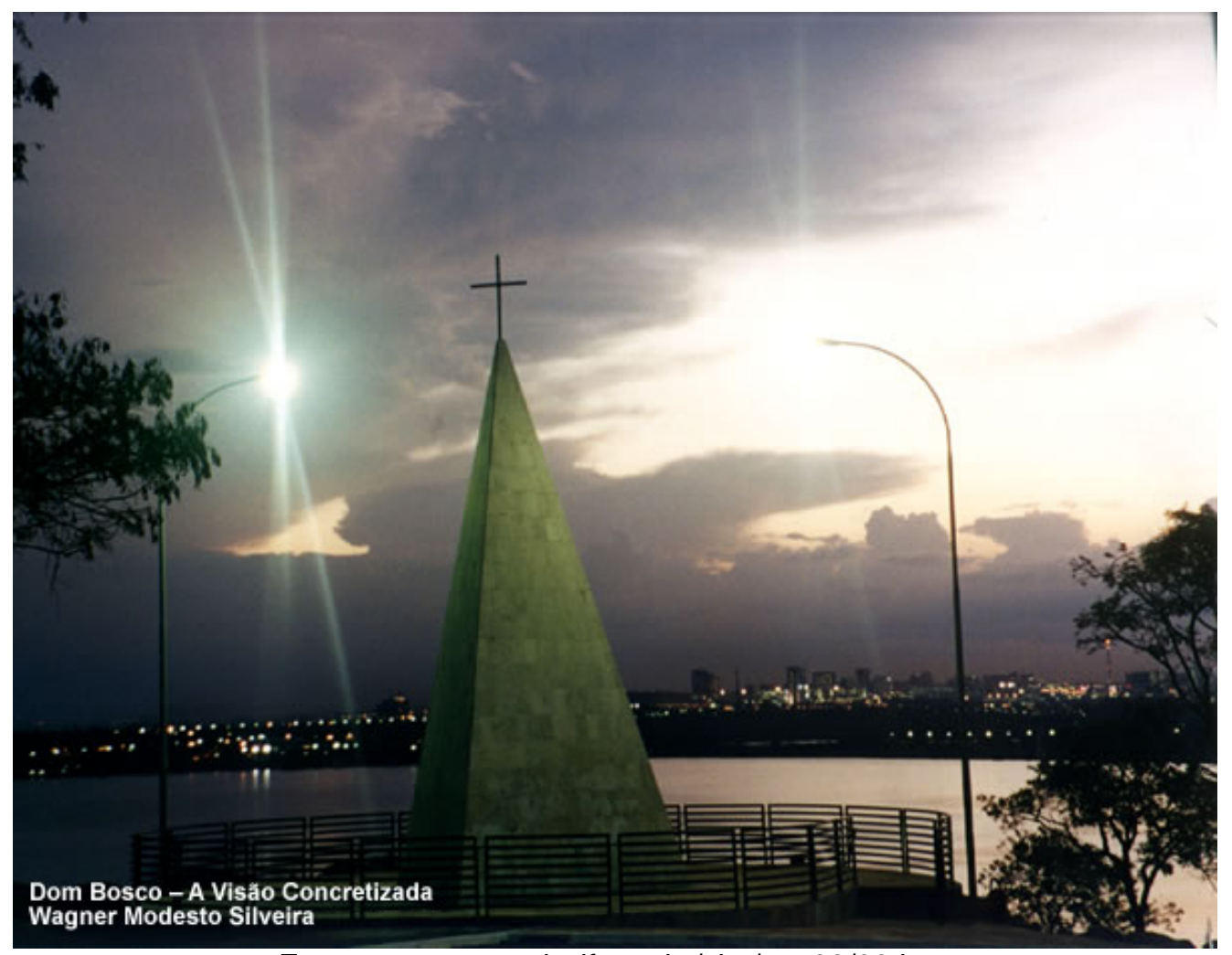

Fonte: www.semarh.df.gov.br/site/cap02/09.htm

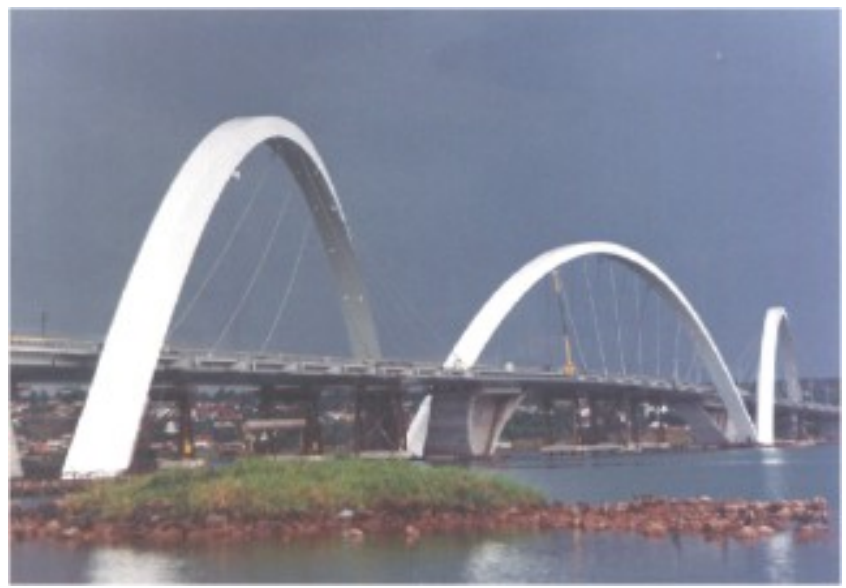

Ponte JK

Fonte: www.so.df.gov.br/obr_pontelago.htm 


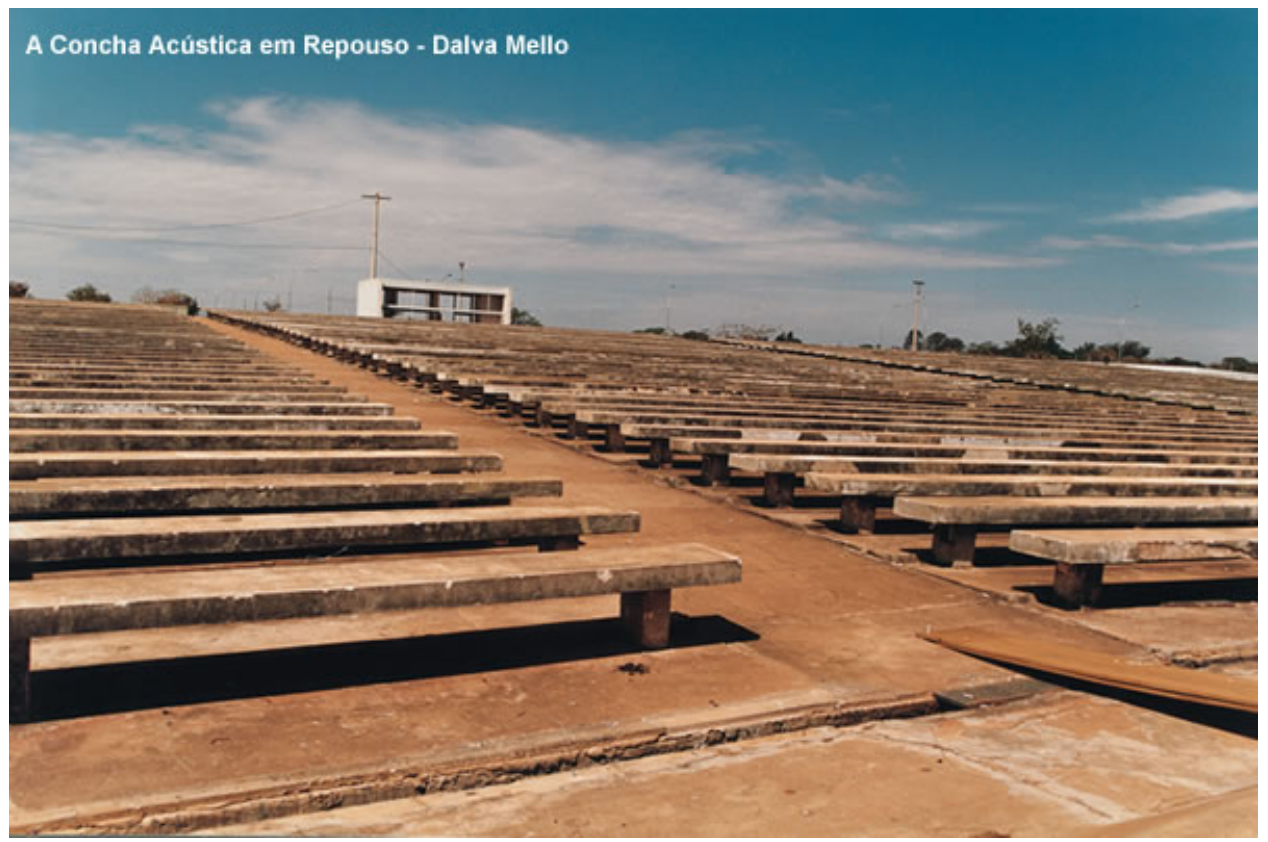

Fonte: www.semarh.df.gov.br/site/cap07/11.htm

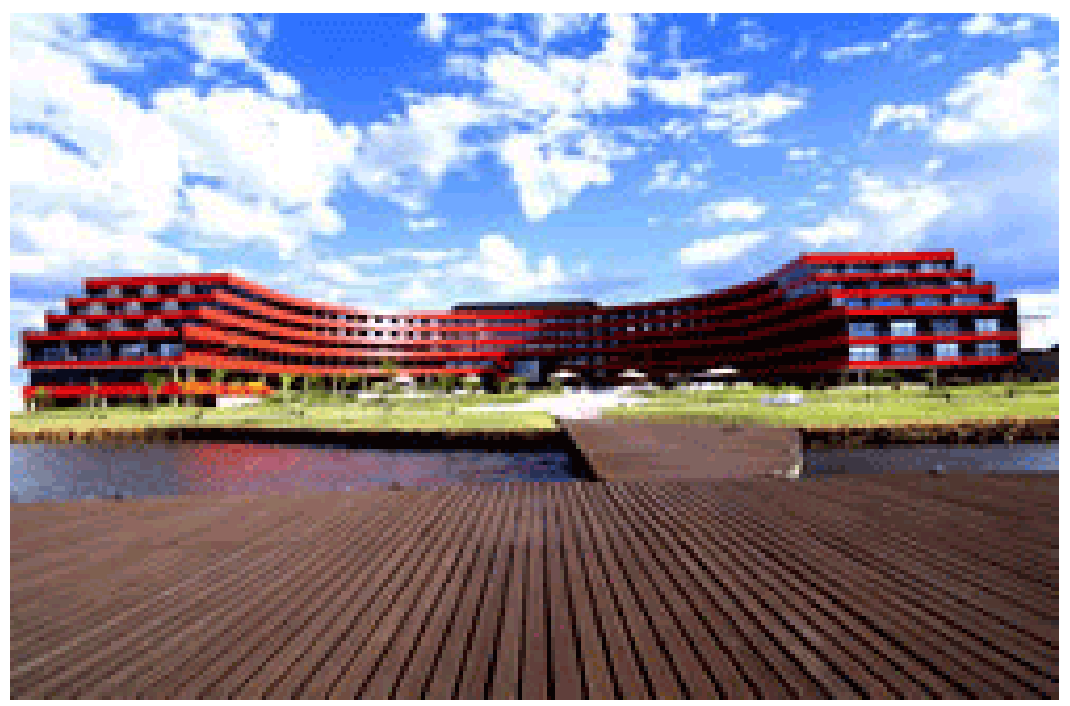

Hotel Blue Tree Park em Brasília Fonte: www.mebf.com.br 


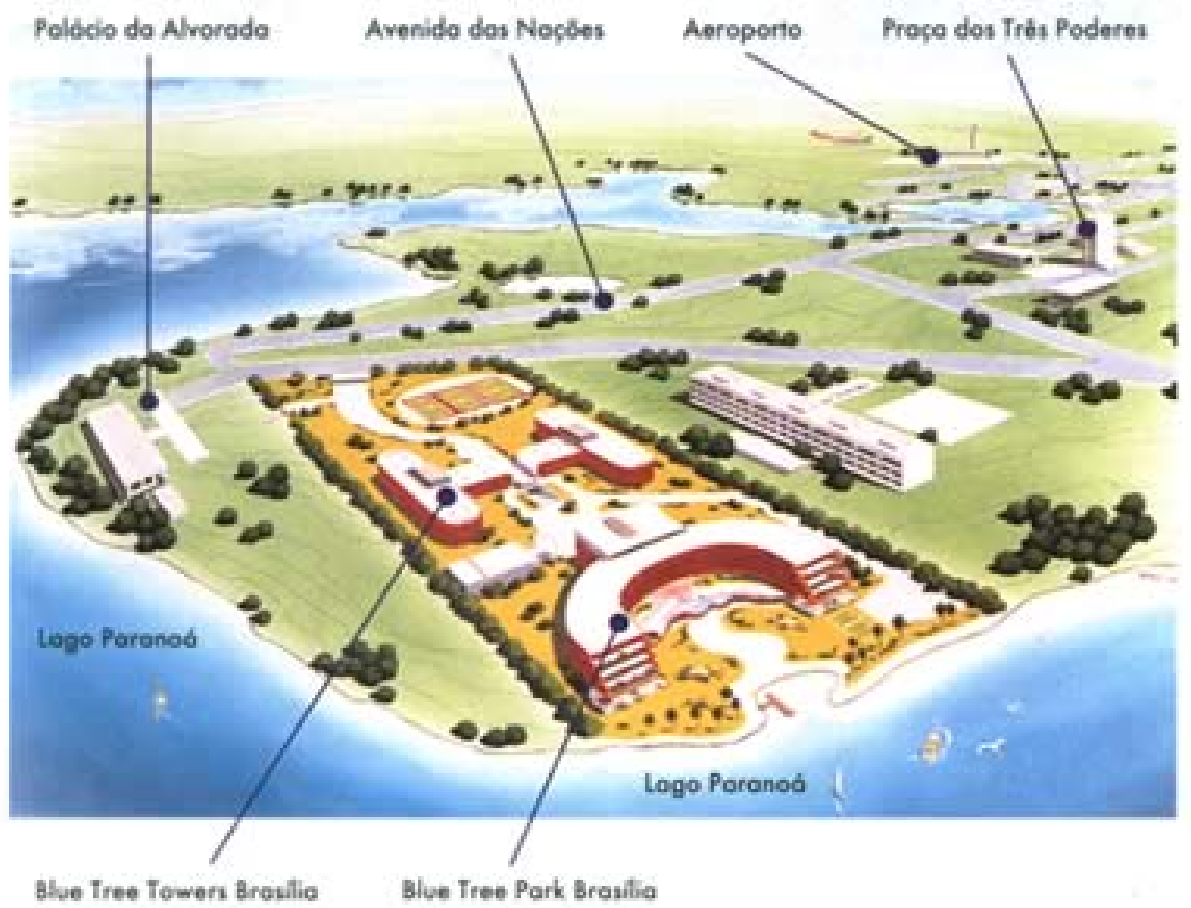

Localização do Hotel Blue Tree Park de Brasília Fonte: www.mebf.com.br

Lakeside Brasília

Projeto Orla 3
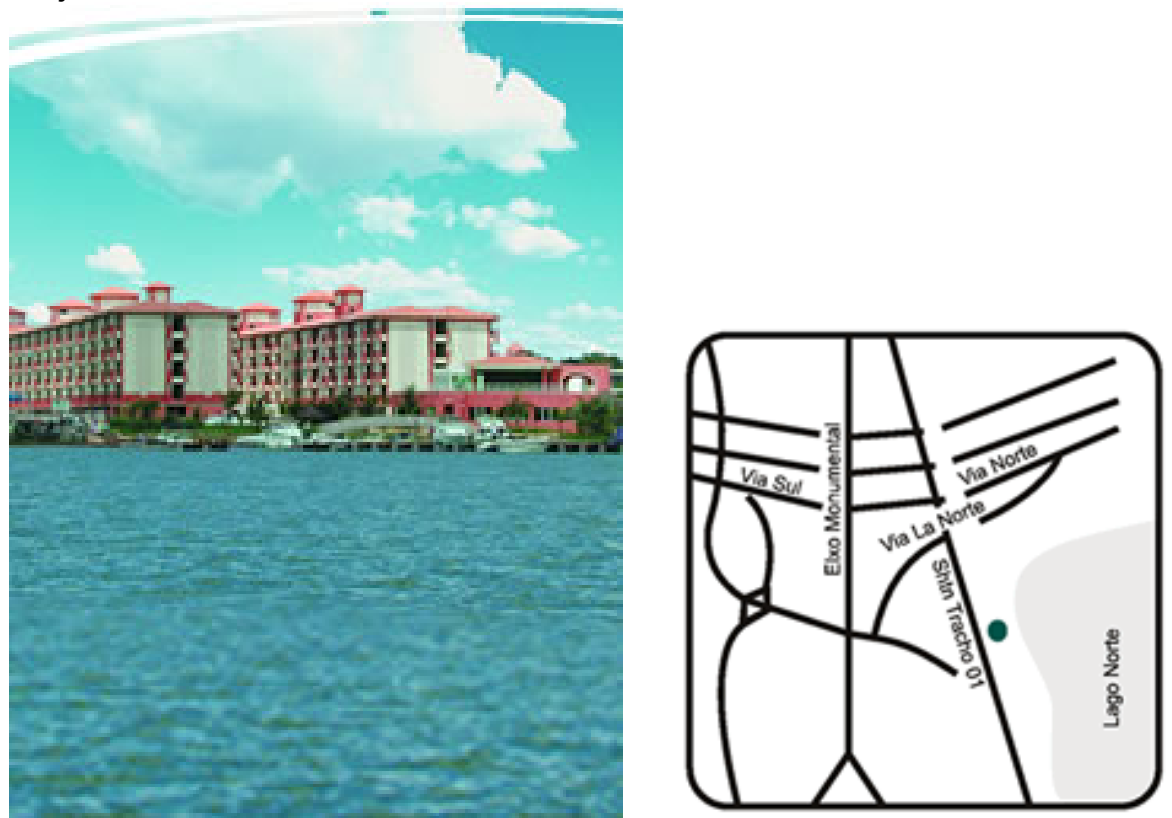

Fonte: www.eswc.com.br/question2.asp 


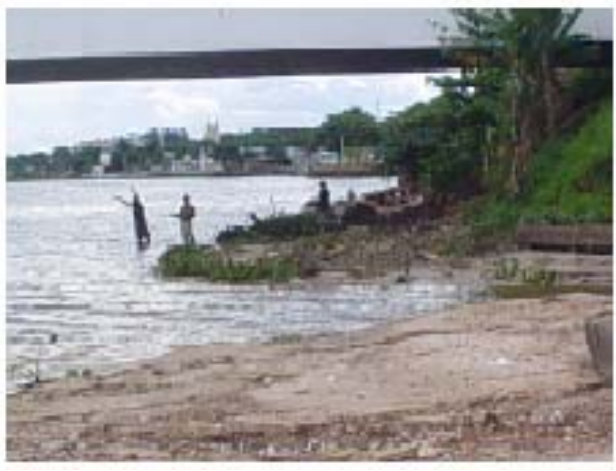

"Prainha" - Asa Sul

Fonte: www.ucb.br/comsocial/ccs/disciplinas/fotojornalismo 


\section{Anexos}

\section{Brasília descobre} o lazer no lago e já tem a terceira maior frota de barcos do país

Mauricio Lima

cidade das fotos ao lado é, sim. Brasília. Para quem acompanha apenas o noticiário político e meteorológico, a capital federal restringe-se ao quadrilátero da Praça dos Três Poderes, com parlamentares e ministros engravatados, magistrados togados e multidōes de funcionários públi$c o s$, além do clima seco, que esturrica a região central do país durante seis meses seguidos. Nos últimos anos, porém, os próprios habitantes de Brasilia estão descobrindo uma outra face da capital - o Paranoá, lago que abraça a cidade de norte a sul, tem águas límpidas e está-se tornando um epicentro de lazer e esportes, capaz de rivalizar com pontos badalados do litoral brasileiro. Com uma freqüência cada vez maior, a paisagem do Paranoá nos fins de semana é marcada por lanchas, jet skis e barcos, além de esportistas praticando remo, vela, fazendo curso de mergulho ou uma variação do surfe para águas sem ondas, o kitesurf, que mistura prancha com pára-quedas. São mais de 10000 embarcações registradas na Delegacia Fluvial do Distrito Federal, o que já confere a Brasília o título de dona da terceira maior frota de embarcaçōes do país, atrás do Rio de Janeiro e de São Paulo, Estados com uma ampla costa oceânica.

Calcula-se que nos fins de semana quase 1000 embarcações se lancem ao Paranoá. Como quase nunca chove entre abril e setembro e o clima é ameno no resto do ano, é uma diversão garantida. Nos últimos dois anos, a frota brasiliense

\section{4 de setembro, 2003 veja}
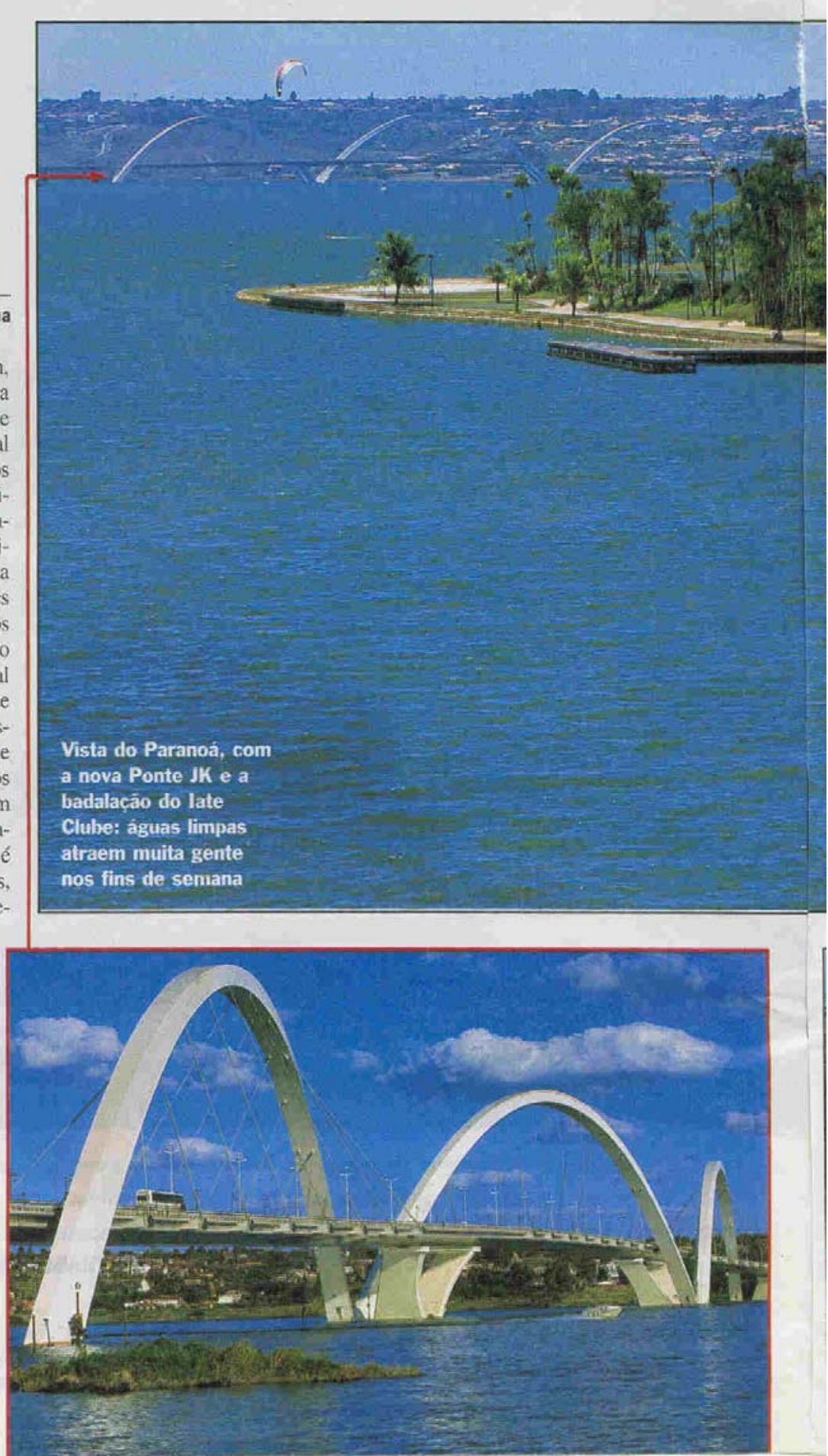

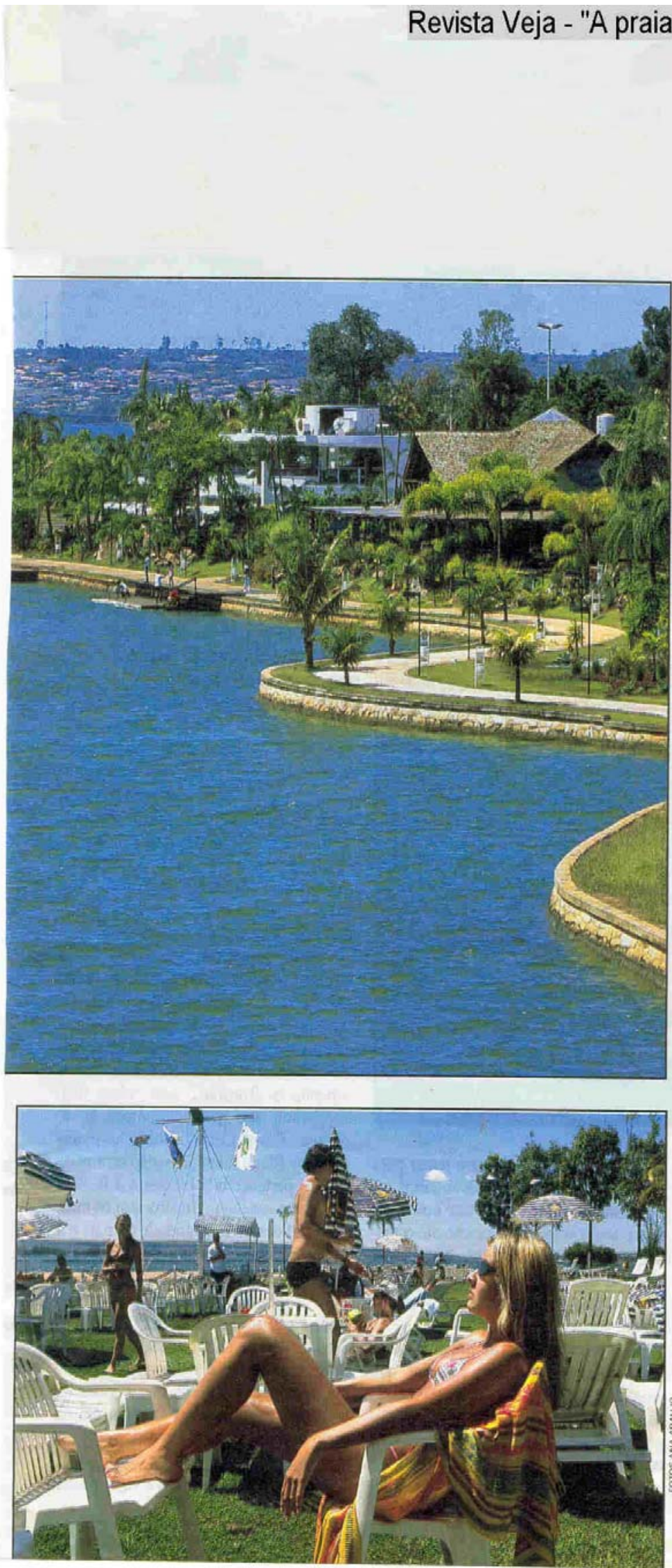

de embarcaçōes cresceu mais de $10 \%$, incluindo barcos modestos, de 2500 reais, até lanchas suntuosas, de mais de 1 milhão de reais. A cada mês, 45 novos barcos são licenciados para navegar no lago. Em 2001, Gerard de Sou$\mathrm{za}$, que tinha uma loja de lanchas em Goiânia, percebeu que $30 \%$ de seu faturamento vinha de clientes brasilienses. Resolveu instalar-se na capital e. hoje, além da loja original. abriu outras duas. Afora o lazer puro e simples, a prática de esportes também vem aumentando consideravelmente. De dois anos para cá, o número de atividades competitivas triplicou. "Não há semana sem uma regata ou disputa de remo". afirma Paulino de Paula Junior, da Delegacia Fluvial do DF. Os atletas amadores preferem utilizar o lago para natação ou um jogo de pólo aquático. É clima de praia no cerrado.

O Lago Paranoá, criado artificialmente, com volume de água equivalente a $30 \%$ da Baía de Guanabara, capaz de encher 300000 piscinas olímpicas, existe há quatto décadas, desde a fundação de Brasília. Sem ele, o clima seco da cidade tornaria 0 ar irrespirável, e parece que, durante anos a fio, os brasilienses entenderam que o lago existia apenas para servir seus pulmões. S6 nos últimos anos os moradores da capital passaram a aproveitar as águas. Os terrenos à beira do lago estão ficando escassos e, nos pontos mais privilegiados, não se compra um pedaço de terra por menos de 1 milhão de reais. Há algumas razōes para essa descoberta tardia do lago. Uma é a qualidade da água. Até o início da década de 90, o esgoto era jogado in natura nas águas e a cidade, naturalmente, procurava se afastar do odor desagradável, embora nunca tenha sido tão agressivo quanto o cheiro do Rio Tietê, em São Paulo. Em 1994, entraram em operação duas estaçōes de tratamento com os métodos mais modernos de purificação de água. Hoje, o Paranoá tem taxa de balneabilidade superior a $93 \%$, o que é considerado uma marca excepcional. Em alguns pontos, a água é tão cristalina que faz lembrar até - sem um pingo de exagero - as paradisíacas praias de Angra dos Reis.

Outro motivo para a recente ocupação do Paranoá é que Brasilia sempre se posicionou de costas para o lago, voltada para o centro do poder. Com exceç̃o dos clubes erguidos na orla, todos os

veja 24 de setembro, 2003 


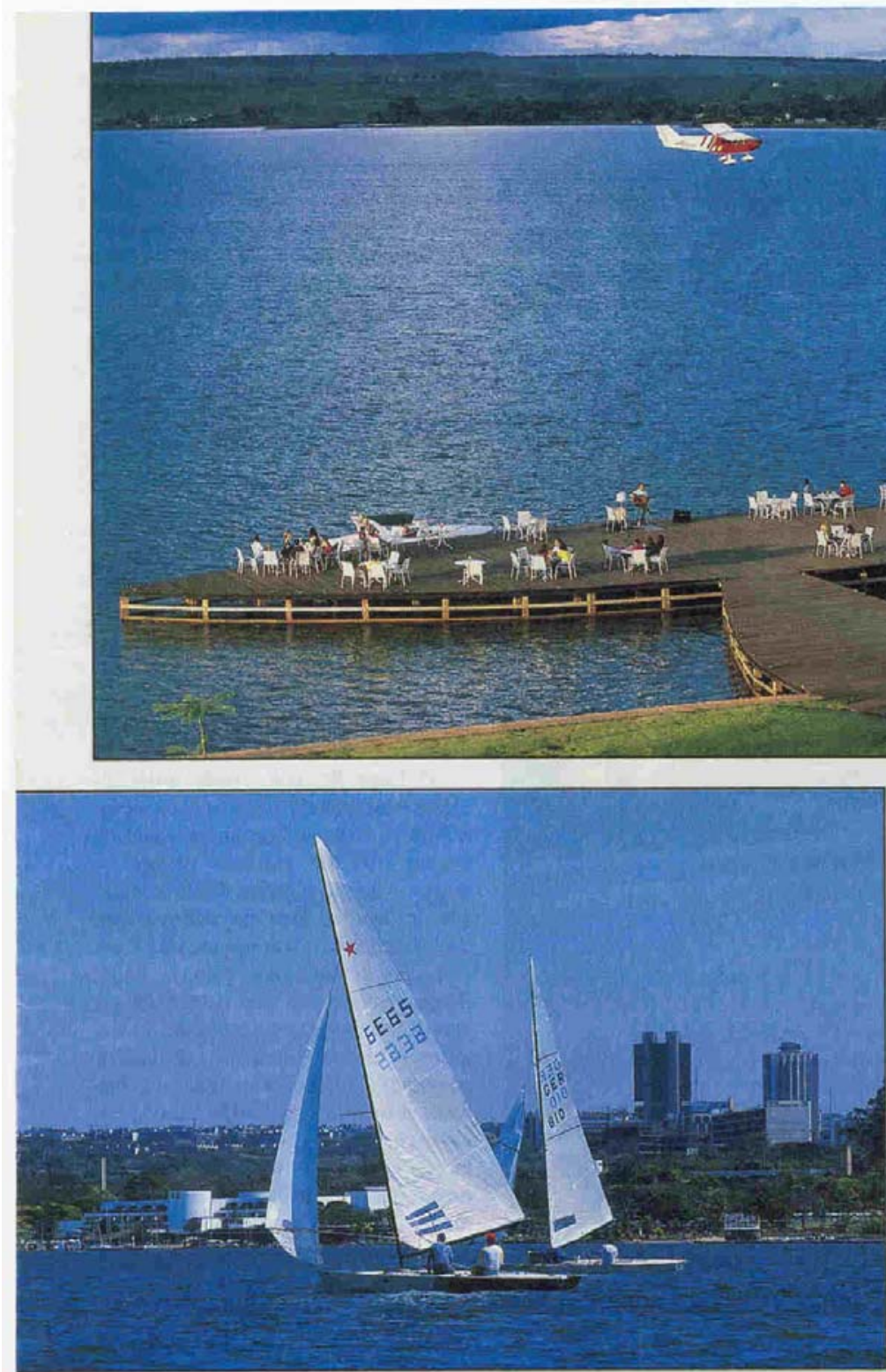

empreendimentos comerciais que surgiam na capital ficavam distantes de suas margens. A lógica mudou completamente. Hoje, praticamente todos os lugares mais freqüentados de Brasflia estão à beira do lago. Nos últimos anos, foram construídas dezenas de restaurantes, bares, marinas, um shopping center e dois mega-hotéis, ambos nas proximidades do Palácio da Alvorada - que. aliás, também está debruçado sobre o lago e guarda em sua garagem uma bela lancha para uso do presidente da República e seus familiares. Recentemente, uma companhia alemã de cola promo-

7224 de setembro, 2003 veja veu, à beira do Paranoá, um jantar para 250 convidados. Os convivas eram recepcionados num dos novos hotéis da orla e transportados de lancha até o restaurante. $\mathrm{O}$ passeio noturno, que incluiu o visual da nova Ponte JK, uma imponente construçâo com arcos transversais, foi um sucesso absoluto.

A explosão náutica de Brasilia já provocou o surgimento de empresas que alugam embarcaçōes para festas noturnas. Além das novidades recentes, antigos empreendimentos estão se adaptando ao foco de atração que o Paranoá exerce. Restaurantes que já estavam ali
O pier de um dos novos hotéis construidos à beira do lago e uma regata de vela: eventos esportivos todas as semanas

mas eram fechados para o lago estão construindo píeres para receber a clientela que chega de barco. No mês passado, até uma academia de ginástica passou a alugar uma embarcação para dar aula de spinning no meio do Paranoá Próximo à barragem do lago, há lugares de água mais límpida, rodeados por uma vegetação cuja exuberância parece desdizer a seca. Ali, é comum a concentração de barcos e lanchas ancorados, cujos passageiros ficam apreciando a paisagem e aproveitando o dia. A prática do luau também está se popularizando, com grupos de embarcaçōes ancoradas até o amanhecer. Brasilia é uma cidade rica, riquíssima até, quando comparada ao resto do Brasil. Cerca de $40 \%$ dos moradores do Plano Piloto, a região central da cidade, pertencem às classes A e B. Sem as cidades-satélites, Brasilia tem os mais altos índices de escolaridade do país e a maior renda per capita. Isso explica a quantidade de lanchas de médio e grande porte. Mais da metade das embarcacōes estão classificadas nessa categoria. Outra febre é a dos jet skịs, que saem em média pelo preço de um carro popular. Mesmo com esse inconveniente, as empresas do setor venderam dois jet skis por dia no ano passado.

Outras fotos em www.veja.com.br 


\section{Áreapara pescaéampliada}

A Lei Distrital 3.066, de autoria do ex-deputado Rodrigo Rollemberg (PPS) e publicada no Diário Oficial do DF na segunda-feira, amplia os limites para a pesca profissional no Lago Paranoá. Os pescadores terāo agora praticamente toda a extensão do espelho d'água para jogar as tarrafas (tipo de rede) em busca do pescado (Leia quadro). São 38 quilômetros quadrados. Antes, a pesca só era permitida nas regiōes próximas ao Córrego do Bananal (braço Norte) e Riacho Fundo (braço Sul).

A ampliação dos locais de pesca preocupa o biólogo Fernando Starling, da Caesb. "Temos que reestudar todo 0 ecossistema para saber se a pesca pode mesmo ser liberada em tantos pontos", pondera. Outra crítica do biólogo é que a lei não especifica as áreas proibidas para os pescadores. 0 texto menciona apenas que não é permitido pescar nas "águas próximas" ao Palácio da Alvorada, à Barragem do Paranoá, à Península dos Ministros e em locais de concentração de atividades de lazer e de práticas esportivas.

Mesmo com a ampliação da área, pescadores garantem que não se consegue pescar tanto quanto há dez anos. Há quem conte que nas época de fartura, os pescadores do Lago Paranoá voltavam para casa, cada um deles, com 200 quilos de peixe.

As tilápias sempre foram a espécie mais pescada. 0 quilo do peixe é vendido por $\mathrm{R} \$ 2,50$ no atacado, e R $\$ 4,00$ nas feiras do DE. Hoje, a pesca de um dia todo (12 horas a postos) rende de 25 a 30 quilos. "A pesca no lago já foi bem mais rentável", resigna-se Geraldo Figueredo, presidente da Cooperati- va dos Pescadores Profissionais do Distrito Federal (Coopelap-DF), entidade com 105 filiados.

\section{SEMINÁRIO}

A sustentabilidade do Lago Paranoá será tema de seminário, amanhã e terçafeira, no auditório da Universidade Católica de Brasilia, na 916 Norte. A abertura será às $8 h 30$, com entrada franca. A idéia é fazer inventário dos problemas do lago e definir estratégias para o monitoramento da Bacia Hidrográfica do Paranoá. 


\section{ONDE PESCAR}

A prática da pesca profissional é permitida em quase toda extensẫo do Lago Paranoá. A lei distrital, de autoria do deputado Rodrigo Rollemberg, proibe a atividade nos seguintes pontos:

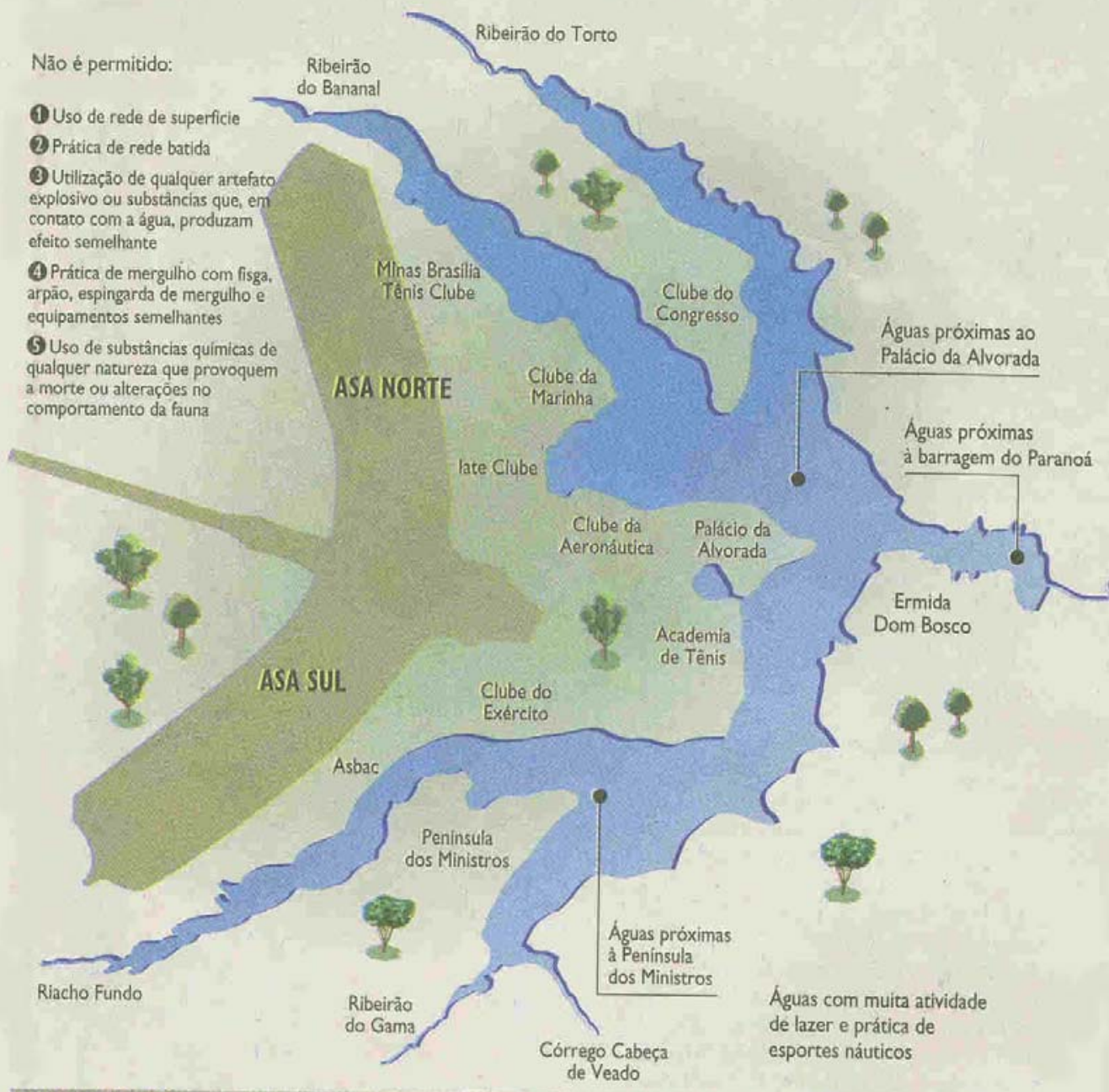

\section{PEIXES NATIVOS}

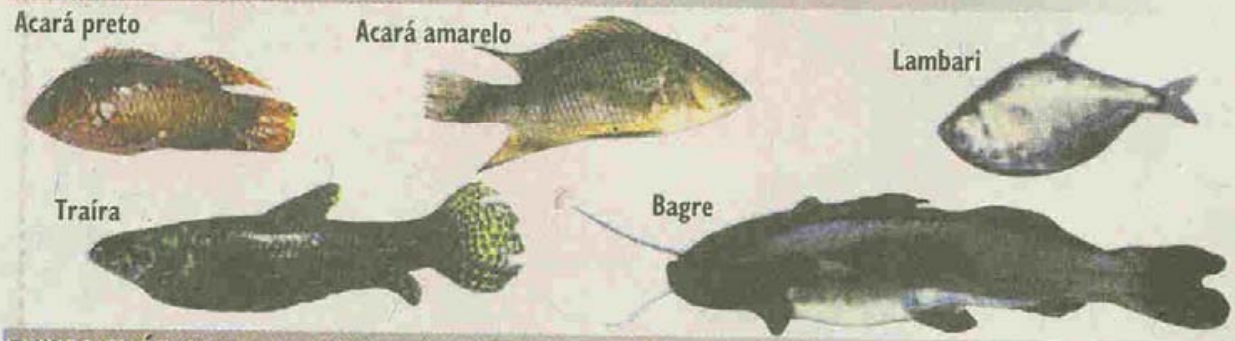

\section{PEIXES EXX́TICOS}

\section{Tambaqui}
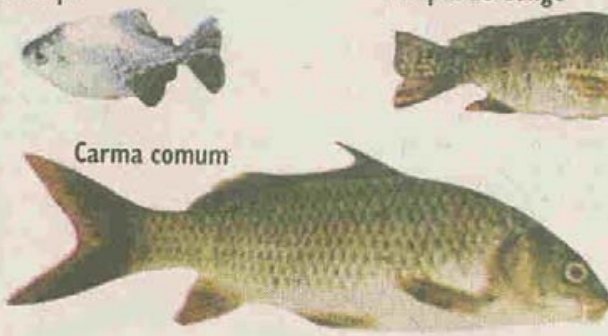

Tilápia do Congo

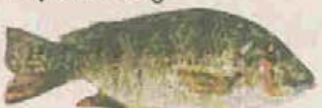

2.

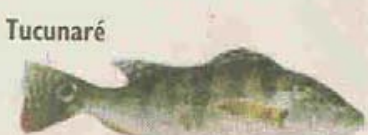

Tilápia do Nilo

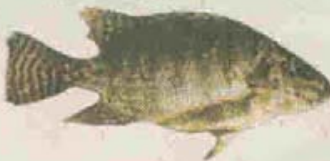


Correio Brasiliense - Turismo em Brasília - 22/06/2003

\section{Investimentos no selor}

0 último levantamento realizado em 2000 pela BC\&VB mostra que o turista é predominantemente do sexo masculino 65\%). A maioria vem de São Paulo. Minas Gerais, Goiás e Rio de Janeiro, por motivo de trabalho, negócio ou para participação em eventos. 0 gasto minimo por dia é de R\$300, com hospedagem, transporte, compra, diversẫo e alimentaçảo. Ainda nẫo existem dados que mostrem quanto o turismo gera de receita para a capital.

Com base na pesquisa e na tendència delecteda pela Organizaçăo Mundial do Turismo (OMT) de que, ate 2020,76\% das viagens realizadas no mundo serăo de curta diśąancia - com duração máxima de quatro horas - a Secretaria de Turismo do Distrito Federal (Setur) tem projetos para otimizar o setor na cidade.

Os investimentos públicos liquidos pre. vistos para o setor este ano estäo aquém das necessidades: apenas R\$ 2 milhoes. Mas a secretaria quer usar adequadamenLes recursos estabelecendo convénios com governo federal, Sebrae, UnB e iniciativa privada. Além disso, a Setur nāo preende gerir os recursos sozinha. Na última quinta-feira, tomaram posse os membros do Conselho Regional de Turismo (Conde. tur), formado por representantes de todos realizaçäo de fóruns para discutir solucōes para os problemas do DF.

No turismo nâo dá para inventar a roda. Brasilia jả tem as atracões. 0 que irá diferenciar é a execução das acçes para melhorar a infra-estrutura", acredita o jeto Eixo Monumental, que visa melhorar subsecretário de Turismo, Sèrgio Flores. a infra-estrutura para os turismos de ne-

Ima das aç̄es para estimular passeios gócios e eventos e civico. Também exis. de curta distância è aproveitar melhor o tu- tem iniciativas para fortalecer o turismo ista de negócios e eventos com a elabora. rural e o náutico. Entre as açöes, estäo câo. junto ao governo federal, de roteiros previstas a reforma do Centro de Con. integrados. "Nosso objetivo é atrair a fami- vençōes, que será concluida no ano que

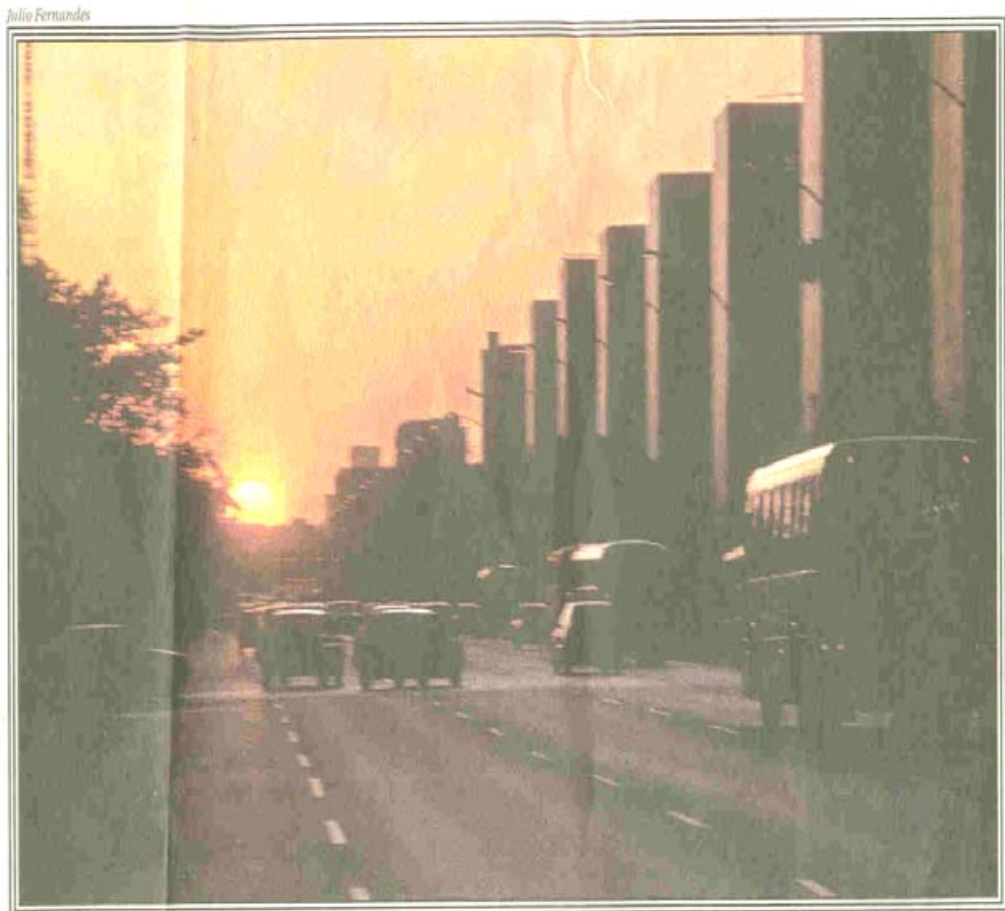

inda segundo a pesquisa, a Esplanada éo segundo lugar mais procurado pelo visitante. Ministérios encantam os turistas

do homem de negócios que vem a Bra. Slla e que nao va embora antes de conhec.'azenda a Chapada dos Veadeiros, as idades históricas e outros" explica Lúcia acha de Lima, secretária de Turismo. as lurismo nautico sera estimulado coma do Poblo pier de acesso ao lago Paranoá e quatro quiosques de alimentação. Outro projeto que está em estudo è o repovoamento de peixes do lago Paranoá para possibiitar a
pesca esportiva. "A pesca é um esporte interessante porque atrai pessoas de todas as camadas sociais, desde o camarada que fica sentado na beira da ponte ao que tem barco próprio", explica o subsecretário ad- junto de Turismo "A pesca tambèm serve como terapia, o que aumenta a qualidade de vida", alega Flores. A promoçāo de grandes eventos nauticos tambem esta entre os obietivos da secretaria.

Outro ponto importante é a capacitaçāo da mäo-de-obra, que contará com o apoio do Senac 0 atendimento será mehorado nos seis Centros de Apoio ao Turista (CAT) ө os taxistas serāo capacitados para pas. sar informaçōes sobre a cidade, como ho rários de funcionamento dos locais de visi. taçâo, entre outros. "Começaremos com os taxistas e estenderemos para outras ca. tegorias", informa o subsecretário. 


\section{Especialistas apostam no diversificado potencial de Brasília para dobrar o número de 2,3 milhões de visitantes anualmente}

\section{Valesca Riviéri}

Imagine a manchete: Brasilia é a cidade do pais que mais atrai turistas nos sete dias da semana. Inacreditável? Entäo se reporte para a seguinte cena: 0 brasiliense, ao sair para trabalhar, se depara na Esplanada dos Ministérios e na Catedral com centenas de ónibus turisticos trazendo alunos do país inteiro para estudar in loco a história da capital federal, então matéria obrigatória nas escolas.

Somem-se a isso grandes eventos nacionais e internacionais acontecendo simultaneamente no Centro de Convençōes, totalmente modernizado, no paviThão do Parque da Cidade e outras várias áreas. A Casa de Chá, na Praça dos Três Poderes, transformada em ponto de encontro de personalidades nacionais. 0 mirante da Torre frequeentado diariamente por centenas de pessoas que năo querem perder a melhor vista do pôr-do-sol da cidade - espetáculo imperdivel no periodo da seca, quando o céu exibe escandalosos tons em degradê.

Também vamos imaginar o turismo regional a todo vapor. Nos finais de semana, o lago Paranoá repleto de turistas praticando pesca esportiva. Grandes competiçōes, de regatas, vôlei de praia e outros esportes, atraindo atletas do país. Nos arredores do Distrito Federal, inúmeras cachoeiras, hotéis-fazenda e cidades vizinhas recebendo brasilienses e turistas de outros estados que procuram a capital para realizar negócios. E depois dão uma esticadinha para não perder as maraviIhas do Planalto Central.

Parece sonho? Mas especialistas da área apostam no potencial turístico de Brasilia para dobrar o número de $2.3 \mathrm{mi}$ Ihōes de visitantes anualmente. Realmente a capital da República soma inúmeras qualidades capazes de impulsionar o setor. A localizaçăo geográfica é o primeiro ponto positivo. Diariamente, 0 Aeroporto Internacional Juscelino Kubitschek - terceiro maior do país - recebe 162 vôos, procedentes das principais cidades brasileiras.

A cidade oferece qualidade de vida com 120 metros quadrados de área verde por habitante, è a terceira mais segura do pais, tem trânsito fluente de veiculos e muitas opçōes de lazer, além dos monumentos: shoppings, restaurantes, cinemas, feiras e outros. Recentemente, Brasilia ganhou um novo monumento, que se tornou o principal ponto de visitaçäo: a Ponte JK, eleita a mais bela do mundo pela Sociedade dos Engenheiros da Pensilvânia Ocidental (EUA),

Correio Brasiliense - 22/06/2003 


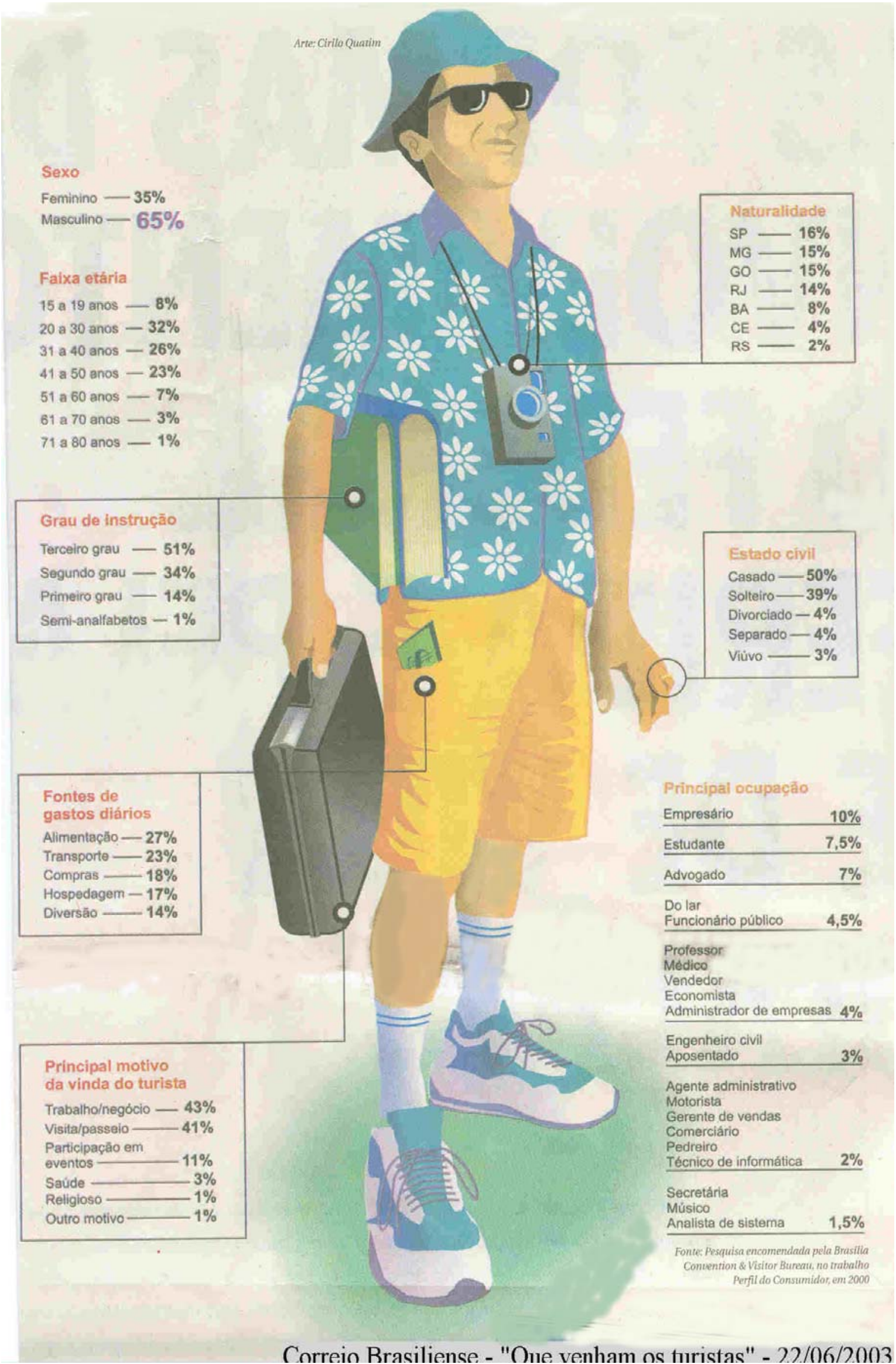


MUITO HOTEL PARA POUCO HOSPEDE

A rede hoteleira é concentrada em 10 .

cais estrategicos e reùne 22 mil leitos. Tambèm oferece diversas categorias de acomodacóes sendo $22 \%$ em ho

tèis 5 estre.

las, $37 \%$ en

4 estrelas.

$33 \%$ em 3

estrelas e

$6 \%$ em ho.

téis 2 estre.

las. E se tem-

po é dinheiro.

os empresá-

rios e turistas

só tẻm a ga.

nhar. Os princi-

pais hotéis fi-

cam a 15 mini.

tos do aeropor.

to. dez minutos

do Setor de Em-

baixadas e cinco

minutos do Con.

gresso Nacional.

Apesar de todos

esses atrativos, da.

dos da Associaçäo

Brasileira da Indústria Nacional de Hotèis pessoas perderam seus empregos nos mostram que nos últimos dois anos a rede hotéis. "Além da crise do furismo mundial noteleira da capital cresceu $60 \%$ Na contra. a cidade está com excesso de leitos e sem măo. a cidade perdeu 56 eventos em 2001 um local para realizar grandes eventos", para a cidade de Goiánia quando o Centro analisa Cruz. A esperança da associaçắo de Convencôes foi fechado para reforma e que o movimento me hore com a revital. Desde entāo os grandes eventos migraram zacāo do Centro de Convencōes.

para outros estados. A rede hoteleira está "O que está comprovaco é que Brasilia com $40 \%$ a $50 \%$ das acomodaçóes cciosas. carece de iniciativas profissionais e de deOs novos hotèis agregam valor á cidade cisóes institucionais para alçar vóos que com arquitetura modema e novas tecnolo. suas potencialidades recomendam", afirma gias, mas chegaram num momento dificil", Cid Franco, diretor-executivo do Brasilia acredita o vice-presidente da associação, Convention \& Visitors Bureau (BC\&VB). A Eraldo da Cnz "A administracâo de Brasilia instituição, sem fins lucrativos, mantida pe. deveria rever a real necessidade de novos la rede hoteleira e mantenedores, è a caphotës antes de liberar os alvarás", acredita. tadora de eventos. Ea inica iniciativa que

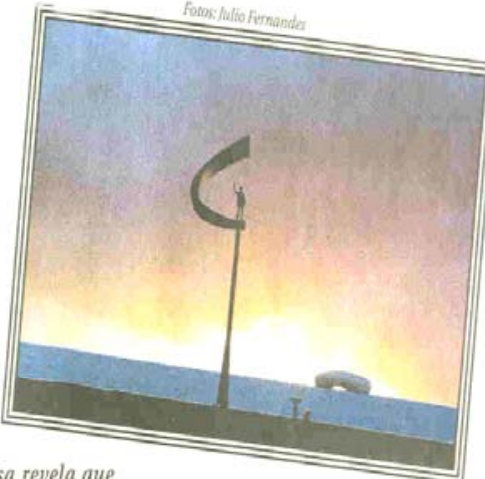

Pesquisa revela que

os pontos mais visitados pelos turistas são mesmo os monumentos da capital: a Catedral é a preferida. 0 Memorial JK e a Praça dos Três Poderes também foram citados.

0 traçado modernista de Oscar Niemeyer impressiona
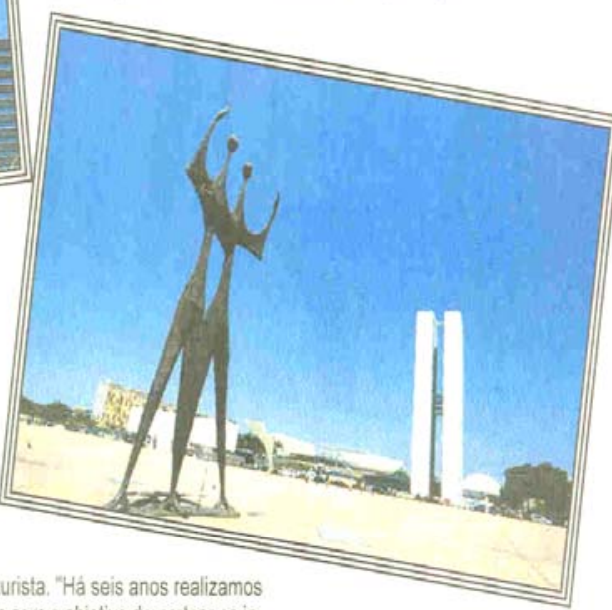

pesquisas com o objetivo de nortear os in.

vestimentos dos vários segmentos do mer- bre o potencial da cidade. "É importante mecado para garantir açōes acertadas para o lhorar os equipamentos, os pontos de visita. setor, explica Franco ça a infra-estrutura e principalmente 0

A diretora do Centro de Excelència do Tu- marketing. Também é preciso despertar 0 rismo da Universidade de Brasilia (UnB), patriotismo brasileiro e mostrar que nảo soNübia Macedo, divide a mesma opiniâo so- mos uma iha da fantasia", afirma

Correio Brasiliense - "Que venham os turistas" - 22/06/2003 


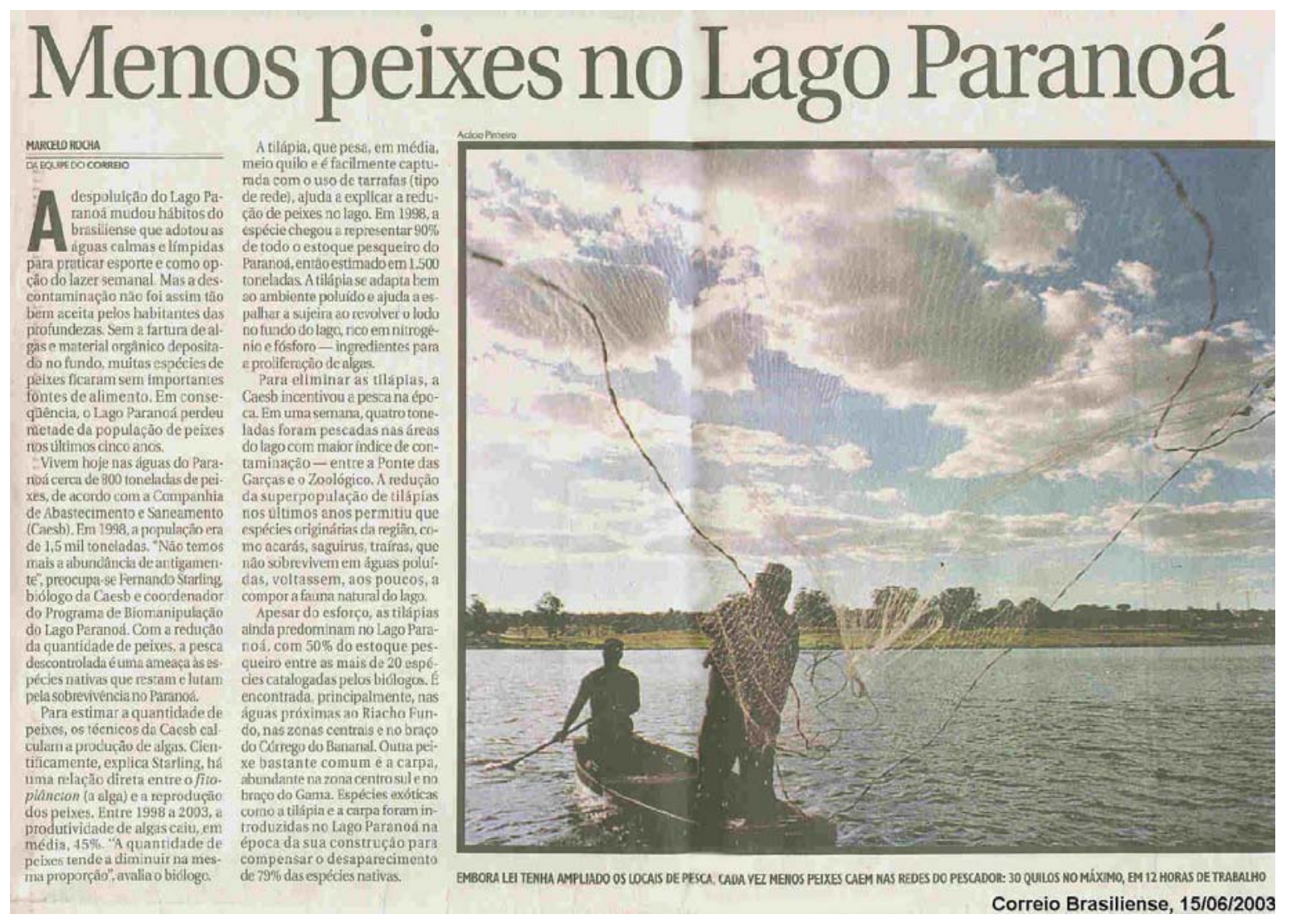




\section{Correio Brasiliense, Caderno C, 360Graus - 14/07/2003}

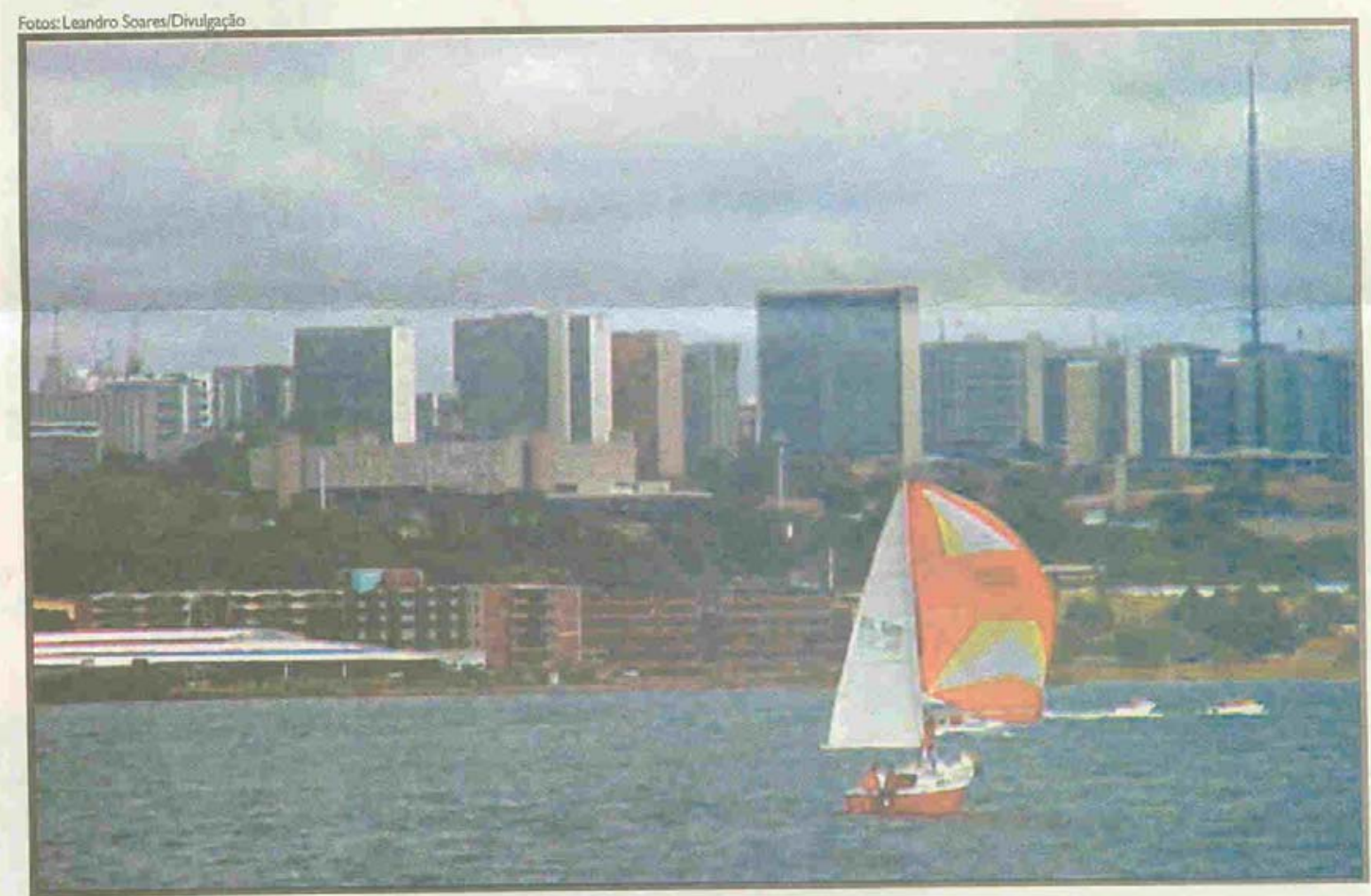

\section{Saias ao Vento}

Brasilia e o lago Paranoá receberam, neste final de semana, um presente muito colorido e bonito. $\mathrm{O}$ campeonato de vela Saias ao Vento, onde mulheres velejadoras participaram bravamente de uma regata. Nas águas cristalinas de um lago despoluído, com o contorno da mais bela ponte do mundo, todos os presentes puderam assistir a evento de suma importância para o esporte náutico de Brasilia. No sábado ensolarado e quente, e no domingo, com muito frio e vento, o campeonato foi um sucesso. Na embarcaçāo de lazer Netumo - com café quentinho, pães de queijo, sanduíches e boa música ambiente-, os convidados de Elenita da Valle,

organizadora do evento, puderam acompanhar a regata de perto, desfrutando da vista e torcendo por suas velejadoras favoritas. Os barcos saíram do pier da marina do Quality Suites Lakeside, mesmo local da premiação, no retorno. Foram quatro regatas nos dois dias. A soma de pontos das campeãs identificou a vitória de Rossana Ramos, com o barco Hookipa. Em segundo lugar ficou Mariana Basilio, com o barco Amanhã e, em terceiro, Cristina Frediani (com Cirrus). O presidente da Federação Náutica de Brasilia, David Baker, descrevendo para os convidados todo o desenrolar da regata, afirmou orgulhoso que "no país, Brasflia é a cidade que mais tem eventos náuticos. Todo fim de semana há competiçâo". Elenita da Valle, promotora do evento, garante que "agora estamos programando um campeonato internacional, tanto masculino quanto feminino". Dito por ela, podem esperar!

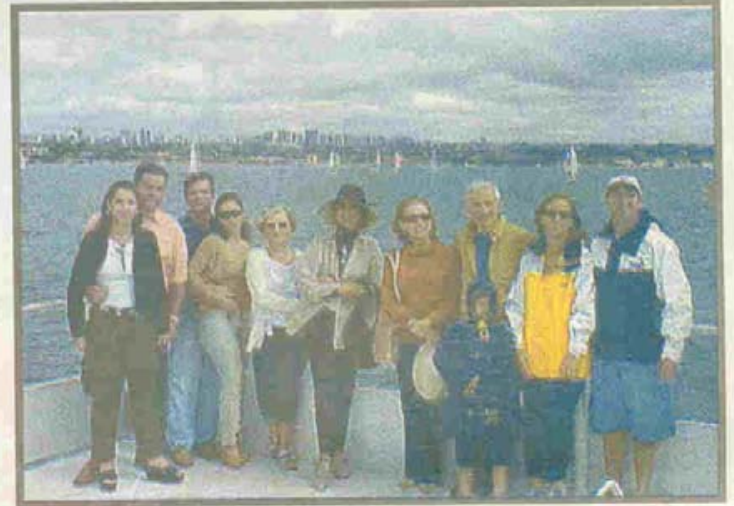

ELENITA DA VALLE (QUINTA NA FOTO, AO LADO DA ADMINISTRADORA DO LAGO SUL, NATHANRY OSÓRIO - COM CHAPÉU) ORGANIZOU O EVENTO

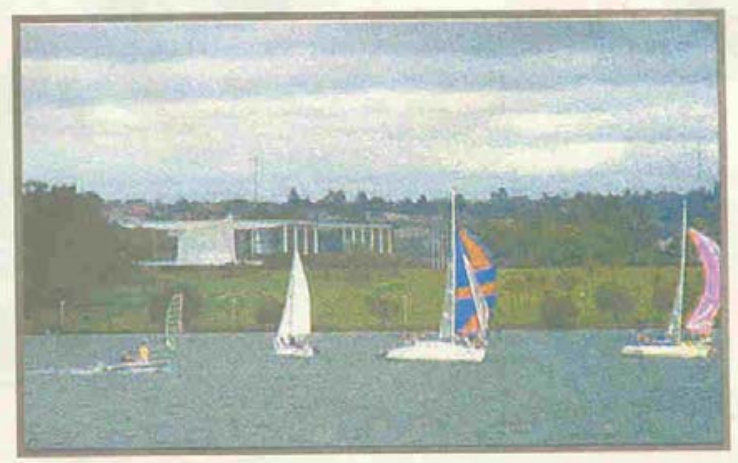




\section{MUSEUS DE BRASÍLIA}

\section{Museus brasileiros e brasilienses, cmo o MAB, procuram saídas para}

TIAGO FARIA

DAEQUIPEDO CORAEIO

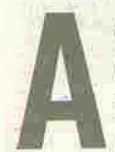
s duas realidades são separadas por alguns poucos quilômetros de distância. De um ponto a outro da cidade, gasta-se apenas cinco minutos de carro. Nos dois lugares, tão separados, a atração é a mesma: uma exposição de arte. Só que, enquanto no Centro Cultural Banco do Brasil (CCBB) as pessoas chegam, se interessam, comentam com amigos, passam a curiosidade adiante - desde abril, apenas na mostra em cartaz, foram 10 mil visitantes -, tudo é oposto no Museu de Arte de Brasília (MAB). Os quadros e esculturas estão lá, o espaço é amplo e a qualidade do acervo, indiscutível. Mas público que é bom, nada.

Ou melhor: quase nada. Na tarde de quarta-feira, depois de duas horas sem receber viva alma, um carro estacionou no único museu de arte da cidade. Era a pesquisadora da Embrapa Marisa de Goes, 51 anos, fã de arte, que aproveitou as férias para conferir a coleção do casal Hecilda e Sérgio Fadel no CCBB. Na saída, decidiu completar o programa com um passeio ao $\mathrm{MAB}$, que não visitava desde 1996. Ao chegar lá, no vazio das galerias, não escondeu a surpresa. "Está maravilhoso. Incrivel como todo mundo vai à exposição Fadel e ninguém vem aqui. Conheço muita gente que nem sabe que existe um museu de arte em Brasilia", diz. O que explica muita coisa é a localização do MAB: escondido próximo à Concha Acústica e o Palácio do Alvorada. Mas essa é apenas parte do drama.

O espanto de Marisa e a comparação entre as duas exposiçôes são ilustrativas como diagnóstico dos museus de Brasilia - e, para além disso, do Brasil. Depois de organizar reuniões com especialistas na área de museologia, o Ministério da Cultura fez uma relação de problemas que atingem os prédios que deveriam servir como vitrine nobre do patrimônio do país. Um deles atinge o MAB diretamente: $a$ dificuldade de divulgação das atividades realizadas.
$O$ contato com o público ainda é raro, quase inexistente. Em um ano inteiro, o MAB recebe cerca de 5 mil pessoas. Um número menor que o de espectadores de uma exposição de curta temporada no CCBB.

O problema não é exclusivo do $\mathrm{MAB}$ e, apesar de atingir em menor escala os museus localizados em áreas mais movimentadas da cidade (como o Eixo Monumental), já foi identificado pela Secretaria de Cultura do DF. "A própria população do DF muitas vezes desconhece os museus que existem na cidade. Nem o Ministério da Cultura sabe", diz Jarbas Silva Marques, diretor de Patrimônio Histórico e Artístico da Secretaria de Cultura.

Para tentar corrigir a distorção, a Secretaria elaborou durante sete meses um guia de museus do $\mathrm{DF}$, que está engavetado à espera de parcerias para a publicação. O objetivo príncipal da coleta de dadosé entregar as informações ao Minc, que desenvolve desde a semana passada as primeiras estra-

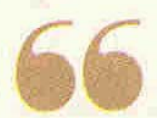

\section{A PRÓPRIA POPULAÇÃO DO DF MUITAS VEZES DESCONHECE OS MUSEUS QUE EXISTEM NA CIDADE. NEM 0 MINISTÉRIO DA CULTURA SABE}

Jarbas Silva Marques

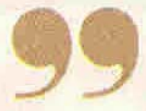

Diretor de Patrimônio Histórico e Artístico da

Secretaria de Cultura 


\section{enfrentar falta de público e as dificuldades de divulgação e patrocinio}

tégias de um Plano Nacional de Museus. De acordo com o levantamento atualizado da Secretaria, a capital federal abriga 36 museus: de ilustres conhecidos, como o Espaço Lucio Costa, na Praça dos Três Poderes, a outros menos populares, como o Museu da Limpeza Urbana, em Ceilândia.

"No caso do DF, o que precisa ser feito em primeiro lugar é a formação de um sistema integrado de museus, que una não apenas aqueles que são gerenciados pelo governo local, mas também os outros. Isso vai ajudar na própria divulgação das instituições", explica José do Nascimento Júnior, coordenador de Museus da Secretaria do Patrimônio, Museus e Artes Plásticas do Minc. No mapeamento das falhas dos museus brasileiros, o Minc identificou a inexistência de campanhas de divulgação. Os museus existem, bem ou mal cuidados. Mas estão separados da sociedade como que por barreiras sólidas.

\section{Ampliação de visitas}

A tentativa de ampliar a freqüência de visitantes nos museus muitas vezes parte das próprias gerências. Soluções individuais e que não chegam a resolver o problema maior: $\mathrm{OMAB}$ - que fechou as portas de 1998 a 2001 para uma reforma de ampliação que nunca saiu do papel por falta de verbas e teve que se contentar com obras de restauração-mantém visitas regulares de alunos da escolas do DF. Mas, por falta de transporte próprio, recebe na maioria das vezes estudantes da rede particular de ensino.

A Secretaria promete conseguir em dois meses um veículo para facilitar 0 acesso de alunos de escolas públicas. Para os visitantes, o conforto das instalaçôes não são dos maiores - na área destinada a um café, há apenas um espaço vazio, à espera de um processo de concorrência pública para a definição de uma lanchonete.

Os problemas parecem pequenos, mas influenciam diretamente na visibilidade dos museus. Até mesmo o Memorial dos Povos Indígenas, localizado à frente do concorrido Memorial JK e que recebe cerca de 10 mil visitantes por mês, sofre com questões estruturais. "Temos que melhorar a iluminação e a sinalização. 0 prédio tem uma aparência de fortaleza, e muita gente acha que ele está sempre fechado", diz a gerente Sandra Wellington. A situação do pequeno estacionamento do Memorial dos Povos Indígenas é um convite à desistência do visitante. Basta algum ônibus parar no local - 0 que freqüentemente acontece - para que nenhum outro veículo encontre vagas livres.

A Secretaria de Cultura, apesar de divulgar que por ano cerca de 1 milhão de pessoas visitam os sete museus sob gerência do GDF, assume que o potencial de público das atraçōes é subvalorizado. "Podemos triplicar esse valor", prevê Jarbas Marques. 0 projeto da Secretaria para tentar o feito está em uma parceria com a Secretaria de Turismo, que, de acordo com Jarbas, está na etapa final. "A Secretaria de Turismo está terminando um projeto de dinamização turística do Eixo Monumental, e está nos planos a integração de todos os museus do Eixo", afirma. Uma dessas propostas é oferecer aos turistas um serviço de ônibus panorâmico que faça o trajeto entre todos os museus da regiăo central de Brasilia.

Enquanto os planos são apenas planos - e enquanto se planeja a construção do grandioso $\mathrm{Mu}$ seu do Conjunto Cultural da República, que deverá ficar pronto em três anos e que custará, em conjunto com uma biblioteca, R\$ 33 milhões em acordo entre governo federal e GDF - as pequenas iniciativas tentam empurrar um trabalho a longo prazo de formação de audiência. "Acreditamos que os jovens, as crianças, vão ser os grandes multiplicadores das idéias do museu", diz Marta Benévolo, gerente do $M A B$, como explicação para a importância das excursốes de estudantes no museu. Para tentar divulgar o espaço, o acervo do MAB já foi levado a lugares como a galeria Ecco e o Conjunto Cultural da Caixa Econômica Federal. "É um trabaIho de formiguinha", continua Marta. O tempo e os esforços do governo dirão se a distância entre os museus, o brasiliense e o turista se encurtará - ou se 0 abismo continuará assim, ainda vasto. 


\section{Referências Bibliográficas}

Antropologia. Brasília: A Capital da Esperança. Dissertação de mestrado em Antropologia da Universidade de Brasília, 1980.

CAESB, (2003). Companhia de Saneamento do Distrito Federal [on-line]. http://www.caesb.df.gov.br, acesso em fev.2004.

CAESB/IBAMA/IEMA, (1999). Operação de Controle Ambiental do Lago Paranoá: Remoção Maciça de Tilápias no Braço do Riacho Fundo. CAESB: Brasília, 1999.

COSTA, L. Brasília, cidade que inventei. Relatório do Plano Piloto de Brasília, p. $12,20,30$.

DORNELLES, L. D. C., DIAS NETO, J. Sugestão para uma exploração racional do Lago Paranoá. Encontro dos Engenheiros de Brasília, 15 à 18 de maio de 1985, 6pp.

EMBRATUR. Carta de Goiás - Agenda Única do Turismo Nacional ano 2000. Brasília, 2000.

ESTEVES, F. Fundamentos da Limnologia. Rio de Janeiro: FINEP, 1988.

FILHO, Américo Pellegrini. Dicionário Enciclopédico de Ecologia e Turismo. São Paulo: Manole, 2000.

FONSECA, Maurílio Magalhães. Arte Naval - $6^{\mathrm{a}}$ Ed., Rio de Janeiro, SDG-MM, 2002. 
GRANDO, J. V., (1989). Considerações sobre estágio larval da ictiofauna e aspectos alimentares de quatro espécies de peixes do Lago Paranoá, Brasília - DF. Brasília, Dissertação [Mestrado], Universidade de Brasília, 115 pp.

INSTITUTO BRASILEIRO DE TURISMO [on-line]. <http://www.embratur.gov.br> acesso em 2003 e 2004.

IPDF. A Política Setorial do IPDF - Plano de Sustentabilidade para o Lago Paranoá. Brasília: GDF/IPDF, 1999.

JORNAL CORREIO BRAZILIENSE, várias edições. 2003 e 2004.

JORNAL DE BRASÍLIA, várias edições. 2003 e 2004.

KUBITSCHEK, Juscelino. Porque construí Brasília. Rio de Janeiro: Bloch, 1975.

MENEZES JR., A. e SARAIVA, R. C. F. Proposta para uma política de preservação do patrimônio cultural e sustentabilidade para o Lago Paranoá . Brasília: GDF/SEC/DePHA., 1999.

MINISTÉRIO DO ESPORTE [on-line]. <http://www.esporte.gov.br/> Acesso em 2003 e 2004.

MINISTÉRIO DO TURISMO [on-line].<http://www.turismo.gov.br> Acesso em 2003 e 2004.

OLHARES SOBRE O LAGO PARANOÁ / Organizado por Fernando Oliveira Fonseca, Brasília: Secretaria do Meio Ambiente e Recursos Hídricos, 2001. 425p.: il.

OLIVEIRA, Jurandir Chaves de. Estudos do Turismo Brasileiro. São Paulo: PGE, 1999. 
ORGANIZAÇÃO MUNDIAL DE TURISMO. Desenvolvimento de Turismo Sustentável: Manual para Organizadores Locais. Publicação de Turismo e Ambiente, 1998.

PLANO ESTRATÉGICO DE TURISMO: Políticas, Estratégias e Programas. Brasília: GDF/SETUR, 1999-2002.

PNDPA (1996). Programa Nacional de Desenvolvimento da Pesca Amadora. Projeto Pesca Amadora, PNUD/BRA/97/012, 47 pp. [on-line]] em <http://www.pescaamadora.com.br> Acesso em 2004.

PONDE, Jayme de Azevedo. Navegação Costeira Estimada. Rio de Janeiro: EMMM, 2002.

PROJETO ORLA BRASÍLIA XXI. Brasília: GDF, 1995.

RELATÓRIO BELCHER - Relatório técnico sobre a Nova Capital da República, p. 28 e 29.

RELATÓRIO CRULS. Relatório da Comissão Exploradora do Planalto Central do Brasil, p. 108-110.

SECRETARIA DE ESTADO DE EDUCAÇÃO DO GOVERNO DO DISTRITO FEDERAL. Brasília: [on-line] <http://www.se.df.gov.br> Acesso em 2004.

SECRETARIA DE ESTADO DE CULTURA DO GOVERNO DO DISTRITO FEDERAL. Brasília: [on-line] <http://www.sc.df.gov.br > Acesso em 2004.

SECRETARIA DE ESTADO DE ESPORTE E LAZER DO GOVERNO DO DISTRITO FEDERAL. Brasília: [on-line] <http://www.sel.df.gov.br> Acesso em 2004.

SECRETARIA DE ESTADO DE TURISMO DO GOVERNO DO DISTRITO FEDERAL. Brasília: [on-line] <http://www.setur.df.gov.br> Acesso em 2004. 
SILVA, E. História de Brasília, p. 305-6.

SIlVA, M., CAVAlCANTI, C. G. S., CORDEIRO, A., CAMPELO, R. E., (1998). Diagnóstico Simplificado da Situação do Lago Paranoá. Brasília: Grupo de Gerenciamento Costeiro do Lago Paranoá, 17 pp.

SINOTO, M.L. A memória e seus abrigos. In: GDF, SEC, DePHA. Boletim Trilhas do Patrimônio, nº 6, dez, 1988, p. 3-5.

TURISMO: In: Enciclopédia Mirador, v.4, p. 1788-1789. 